\title{
Use and Abuse of Antidumping by Global Cartels
}

\author{
Arevik Gnutzmann-Mkrtchyan ${ }^{12}$ and Martin Hoffstadt ${ }^{1}$ \\ ${ }^{1}$ Leibniz University of Hanover \\ ${ }^{2}$ CESifo Munich
}

November 2020

\begin{abstract}
Antidumping creates opportunities for abuse to stifle market competition. Whether cartels actually abuse trade policy for anticompetitive purposes remains an open question in the literature. To address this gap, we construct a novel dataset that matches cartel investigations with trade data at the product level. We then estimate the world import price and quantity effects of antidumping in cartel products. We find that the use of antidumping in cartel industries helps to maintain higher world import prices and lower quantities during cartel periods, and to induce the establishment of a cartel. The effect is present both for antidumping cases that result in duties and cases that are withdrawn by the petitioning industry.
\end{abstract}




\section{Introduction}

It is well documented that private firms aim to establish and maintain cartels in order to gain the profits of successful collusion (Ivaldi et al., 2003; Harrington Jr, 2017). They have incentives to use policy tools of international trade when facing defection risk, new competitors or to sanction non-members. Anecdotal evidence suggests that targeted trade protection measures, such as antidumping laws, serve cartels to establish and maintain collusion. For instance, Evenett et al. (2001, p. 1228) refer to the citric acid antitrust case where U.S. cartel firms filed antidumping petitions to block the market entry of Chinese producers that threatened the cartel's stability. Possibly unaware of the existence of the cartel at the same time, the United States International Trade Commission (USITC) imposed antidumping duties against the Chinese firms. To avoid such anticompetitive abuse of trade protection, Hoekman et al. (1997) propose the introduction of antitrust criteria into antidumping laws.

Whether or not cartels use antidumping laws for anticompetitive purposes remains an important gap in the empirical literature. This is surprising given the long historical linkages between antitrust and antidumping legislation (Blonigen and Prusa, 2016, p. 111), a strong theoretical foundation (Staiger and Wolak, 1992; Prusa, 1992; Zanardi, 2004b), and numerous anecdotal links between cartels and antidumping (Irwin, 1998; Evenett et al., 2001; Harrington Jr et al., 2006; Beyer, 2010). This research question is of particular importance as antidumping has be-

come one of the most favoured trade policy tools, while globalisation processes contribute to the global reach of collusive motives. Empirically, the use of antidumping policy is associated with reductions in trade (Vandenbussche and Zanardi, 2010; Egger and Nelson, 2011) and trade deflection (Bown and Crowley, 2007). As a result, Prusa (2005, p. 683) concludes that antidumping laws produce economically more harmful effects than dumping itself.

To the best of our knowledge, Messerlin (1990) is the only contribution that addresses ev- 
idence of widespread use of antidumping in cartel industries. Looking at the European Commission's antitrust cases in 1980-1987, the paper documents that one quarter of these cases were dealing with products that were at the same time involved in antidumping investigations. Messerlin (1990, p. 491) finds that the firms' benefits of antidumping protection outweighted later antitrust fines, predicting the number of antidumping cases to increase in the future, as we indeed observed in the past 30 years (Zanardi, 2004a; Bown, 2008).

A number of theoretical studies demonstrated that the use of antidumping can be abused to foster collusive outcomes. Staiger and $\operatorname{Wolak}(1989,1992)$ show that the mere existence of antidumping laws leads to lower output and trade volumes, and higher prices, both via the threat of antidumping and actual antidumping measures. This happens both when the domestic producer is a monopolist (Staiger and Wolak, 1989) and when the domestic market is competitive (Staiger and Wolak, 1992), and in particular in states of low demand. Prusa (1994) demonstrates that antidumping creates a price floor for foreign firms targeted in antidumping investigations, which leads to a change in pricing behaviour. Prusa (1992) discusses industry-withdrawn antidumping petitions as a signal of a collusive out-of-court agreement between domestic and foreign producers. Extending the model of Prusa (1992), Zanardi (2004b) argues that the likelihood to achieve an out-of-court agreement depends on the coordination cost within the cartel and on the bargaining power of the petitioning domestic industry. ${ }^{1}$

This paper contributes by analysing empirically whether antidumping helps global cartels to initiate and maintain collusion. We estimate the world import price and quantity effects of antidumping investigations before, during and after cartel activity to isolate different channels of impact. Analysing cartel case studies, we identify several important mechanisms, how trade policy can be used by cartels for collusive purposes. While antidumping cases initiated before the cartel start are a powerful mechanism to induce cartel agreements (Irwin, 1998), antidump-

\footnotetext{
${ }^{1} \mathrm{~A}$ famous example is the case of the U.S.-Japanese semiconductor industry (Irwin, 1998).
} 
ing cases initiated during cartel periods help cartels to react to deviating cartel members (Beyer, 2010, p. 3), and to react to the market entry of new competitors (Evenett et al., 2001, p. 1228). Motivated by theoretical models of antidumping and anticompetitive behaviour, we also separately look at antidumping petitions later withdrawn by the petitioning industry, investigations that result in no duties being imposed, and antidumping duties.

As numerous countries simply lack the resources to prosecute and sanction anticompetitive behaviour (Hoekman et al., 1997, p. 399), researchers can only use the sample of cartels from countries that have the resources to conduct antitrust investigations. ${ }^{2}$ Moreover, antitrust authorities are restricted by national borders, while the activities of some cartels are of continental or even global reach (Levenstein et al., 2015). We circumvent this limitation by focusing on the sample of global cartels, i.e. those that operate on at least two continents. Hence we define a product to be a cartel product if it is included in at least one antitrust investigation on global cartels in our sample. Empirically, the impact of these cartels is visible in world import prices and quantities.

Our identification strategy looks at the impact of antidumping in cartel products on world import prices and quantities relative to antidumping in non-cartel products, cartels without antidumping, and products not involved in either antidumping or cartels. We thus estimate whether antidumping, a bilateral measure, is able to affect world import prices and quantities when it is used in cartel industries for strategic purposes.

The empirical analysis results from intensive data collection and matching procedures. First, we construct a novel cartel dataset that matches product descriptions from the Private International Cartels Dataset (PIC) to 6-digit Harmonised Classification (HS) product codes. For this purpose, we review legal antitrust case documents of global cartels to identify the relevant products. Our data covers global cartels for the period from 1992 and 2014. Second, based on the

\footnotetext{
${ }^{2}$ In fact, some countries pro-actively attempt to destabilise cartels with the introduction of leniency programmes (Miller, 2009).
} 
6-digit Harmonised Classification, we are then able to match cartel products with the Global Antidumping Database (GAD). The obtained dataset of twin antidumping and antitrust cases allows us to define the timing of antidumping cases relative to antitrust investigations. This allows us to estimate whether antidumping investigations before, during or after cartel periods help global cartels to raise world import prices.

Key results suggest that antidumping laws serve as a collusive device for global cartels. We find that both withdrawn antidumping petitions and antidumping duties in cartel industries lead to increased world import prices, which is in strong contrast to the impact of withdrawn antidumping petitions and antidumping duties in non-cartel industries. Antidumping duties imposed before the cartel period raise world import prices by 12 to $41 \%$, and antidumping duties imposed during the cartel period raise world import prices by 15 to $27 \%$. Antidumping cases that are withdrawn during the cartel period are associated with higher world import prices by 26 to $47 \%$. These strong effects come on top of the cartel effect, that on average raises world import prices by 9 to $12 \%$ during the proven cartel periods.

This paper continues with Section 2, where we discuss the existing relevant literature. In Section 3 we identify mechanisms and motivations for the use of antidumping laws in cartelised industries. In Section 4 we describe the construction of the dataset and provide descriptive statistics. In Section 5 we present our estimation strategy. Section 6 discusses the results in the light of the identified mechanisms and Section 7 concludes.

\section{Background on Antidumping and Competition}

Our research question is embedded in two strands of literature: first, on the use of antidumping policy (Anderson, 1992, 1993; Bown and Crowley, 2013; Flaaen et al., 2020) and, second, on

the determinants of cartel success (Levenstein and Suslow, 2006; Röller and Steen, 2006; Fonseca and Normann, 2012; Bernheim and Madsen, 2017). The increasing number of countries 
using antidumping legislation since 1990 has motivated extensive research on the implications of antidumping laws (Bown, 2008). But while research on the implications of antidumping laws has produced the hypothesis that the increasing use of antidumping policy may be linked to cartel behaviour, most of at least 125 years of research on the determinants of cartel success (Connor, 2014a, p. 252) has paid little attention to the role of antidumping investigations.

As a matter of fact, the link between antitrust and antidumping legislation dates back to the early 20th century, when a number of Western developed countries began to regulate large cartels and monopolies (Blonigen and Prusa, 2016, p. 111). Beginning with the Clayton Act of 1914, the United States prohibited a number of anticompetitive policies. One of these policies was to price low with the intent of driving competitors out of the market - a strategy nowadays known as predatory pricing. Only two years later, the same principle was applied towards imports in the first Antidumping Act of the United States. According to Viner (1966, p. 242), this step came as a response to the highly cartelised German industries that were selling excess capacity at low prices in the U.S. market. Staiger and Wolak $(1989,1992)$ formalise this behaviour in a theoretical model, which shows that firms dump their excess capacity in foreign markets in times of low demand. Similarly, Brander and Krugman (1983) demonstrate that rivalry between oligopolistic firms leads to dumping in the home market of the rivalling firm. However, while the threat of cartels played a key motivation in the development of antidumping laws, the role of antidumping laws in cartel formation and stabilization has been unnoticed until the late 1980s and early 1990s (Messerlin, 1990; Staiger and Wolak, 1992; Prusa, 1992). ${ }^{3}$

The only empirical contribution that systematically links antidumping and antitrust cases is the study on the European chemical industry by Messerlin (1990). For the European Commission's antitrust cases between 1980 and 1987, Messerlin (1990) observes that one quarter of these cases were dealing with products that were also involved in antidumping investigations.

\footnotetext{
${ }^{3}$ Relatedly, Agnosteva et al. (2020) model show that preferential trade liberalisation improves cartel discipline.
} 
Messerlin (1990, p. 491) finds that the firms' benefits of antidumping protection outweighted later antitrust fines, leaving him to expect the number of antidumping cases to increase in the future. ${ }^{4}$ Some 20 years later, this expectation became a reality (Zanardi, 2004a; Bown, 2008). ${ }^{5}$

A number of theoretical models address the question whether a cartel of domestic and foreign firms has an incentive to strategically exploit antidumping investigations (Staiger and Wolak, 1989, 1992; Prusa, 1992; Veugelers and Vandenbussche, 1999; Zanardi, 2004b). Staiger and Wolak $(1989,1992)$ show that the mere existence of antidumping laws leads to lower output and trade volumes, and higher prices, both via the threat of antidumping and actual antidumping measures. This happens both when the domestic producer is a monopolist (Staiger and Wolak, 1989) and when the domestic market is competitive (Staiger and Wolak, 1992).

Modelling the antidumping procedure in the U.S., Prusa (1992) shows that domestic firms have an incentive to file antidumping petitions in order to align defecting foreign firms in an out-of-court agreement - a process after which the antidumping petition is withdrawn. As a result, Prusa (1992) concludes that a withdrawn antidumping case could be a signal of a collusive agreement between domestic and foreign industry. For the antidumping procedure in the EU, Veugelers and Vandenbussche (1999) show that antidumping policy can both have procompetitive and anticompetitive effects, depending on the initial market structure, i.e. whether domestic and foreign firms are symmetric or asymmetric competitors.

The theoretical implication of Prusa (1992) is that domestic industries would always prefer to withdraw their petition and reach an out-of-court agreement with the foreign firm (Zanardi, 2004b, p. 96). As this was not observed in practice, Zanardi (2004b) extends Prusa's model to account for coordination costs between firms and bargaining power of the domestic indus-

\footnotetext{
${ }^{4}$ Moreover, it is well-documented that the number of antidumping petitions increases after macroeconomic shocks (Knetter and Prusa, 2003).

${ }^{5}$ In contrast to the 1980s when Australia, Canada, the EU and the USA accounted for $73.1 \%$ of antidumping investigations, Bown observed that since 1995 39.5\% of antidumping investigations were initiated by "new user" countries, such as Argentina, Brazil, Colombia, India, Indonesia, Mexico, Peru, Turkey and Venezuela.
} 
tries, which implies that the domestic industry withdraws its antidumping petition only in two situations. First, if coordination cost among the domestic and foreign firms are low, an outof-court agreement is negotiated and the antidumping petition is withdrawn. This may be the case when the cartel consists of only a few members that are able to coordinate an out-of-court agreement. Second, if the domestic firm is a small firm that has little bargaining power towards its government, the chance of the antidumping petition leading to the imposition of antidumping duties is low, which gives the firm an incentive to negotiate an out-of-court agreement. In contrast, domestic industries that employ larger shares of the working population typically enjoy higher levels of bargaining power towards their government. This increases the likelihood for antidumping petitions to lead to the imposition of antidumping measures, implying that firms with high bargaining power can use antidumping petitions at least as a credible threat align foreign competitors (Zanardi, 2004b, p. 105). Moreover, Conconi et al. (2017) show that bargaining power also depends on electoral cycles.

Prusa (1994) demonstrates that antidumping laws affect both domestic and foreign firms' pricing behaviour, even if duties are never levied. ${ }^{6}$ According to Prusa (1994), foreign firms have an incentive to increase prices in order to decrease the chance of a less-than-fair-value determination. As a consequence, domestic firms may profit from the price increase of the foreign firm by raising their prices, too. However, domestic firms also have an incentive to decrease their price in order to impact the injury determination. In the words of Zanardi (2004b), the optimal pricing strategy for domestic firms likely depends on coordination cost and bargaining power.

Motivated by the theoretical models of Staiger and Wolak $(1989,1992)$ and Prusa (1992), the following contributions focused on the empirical assessment of the anticompetitive effects of antidumping. More specifically, it is debated whether the withdrawal mechanism proposed

\footnotetext{
${ }^{6}$ Blonigen and Park (2004) demonstrate that foreign firm's pricing strategy depends on expectations concerning possible $\mathrm{AD}$ enforcement.
} 
by Prusa (1992) indicates tacit collusion. The empirical results are mixed. On the one hand, withdrawn antidumping petitions were not associated with significant effects on trade in the antidumping investigations in the U.S. between 1980 and 1985 (Staiger and Wolak, 1994) and between 1990 and 1997 (Taylor, 2004). On the other hand, Zanardi (2004b) uses the entire 1980-1997 U.S. data and concludes that withdrawn antidumping petitions indicate tacit collusion. Similarly, Rutkowski (2007) finds for the European Union's antidumping cases between 1996 and 2004 that withdrawals likely signalled tacit collusion. Nevertheless, the key problem in this strand of the literature concerns the fact that evidence of collusion is difficult to establish, creating a challenge to observe the unobservable (Connor, 2014a; Blonigen and Prusa, 2016).

In the absense of cartel data, it has been assessed empirically whether and how domestic industries benefit from antidumping protection. Konings and Vandenbussche (2005) demonstrate for more than 4,000 EU producers that eventual antidumping protection had positive and significant effects on domestic markups. In a later contribution Konings and Vandenbussche (2013, p. 316) add that antidumping protection had positive effects on domestic sales of non-exporting firms, while sales and exports of exporting firms decreased. Nieberding (1999) assesses the implications of antidumping measures for domestic market shares, finding that firms receiving antidumping protection increase their domestic market power, while firms who had their petition rejected experience a decrease in market power. In contrast, Reynolds (2013) finds that domestic firms in the U.S. semiconductor and tapered roller industries were not able to increase their market shares through antidumping protection.

\section{Use and abuse of antidumping laws: Mechanisms}

This section reviews cartel case studies and provides an overview of three mechanisms that motivate globally active cartel firms to engage in predatory dumping or to file antidumping petitions either directly in the home market or via subsidiaries abroad. At the core of these 
mechanisms is the question how cartels initiate and maintain cartel agreements. The initiation of cartels requires some form of coordination in order to negotiate the initial cartel agreement. While cartels are active, they not only face a challenge to coordinate prices and quantities, but they need to develop mechanisms to respond to defecting cartel members and to the market entry of new competitors (Levenstein and Suslow, 2006). In the cartel literature, examples of dumping and abuse of antidumping laws is discussed in individual case studies (Evenett et al., 2001; Harrington Jr et al., 2006). We review these case studies and add examples from our dataset to the discussion to identify main impact mechanisms discussed below.

\subsection{Before the Cartel}

Irwin (1998) assesses a case where the U.S. antidumping law helped governments and industries to jointly establish a global cartel. This case of the 1970s semiconductor industry originates from a Japanese subsidy programme that aimed to increase the efficiency and capacity of Japan's semiconductor exporters. As a result of the programme, Japanese producers increased their exports of semiconductors to many countries, including the United States. The increased quantities of semiconductors led to a global price reduction of semiconductors, which led to the filing of an antidumping petition in the United States by U.S. firm Micron. Following the initiation of the antidumping investigation, a suspension agreement was negotiated with support of the U.S. Department of Commerce and the Japanese Ministry of International Trade and Industry (MITI). Since both Micron and several Japanese producers were caught in a cartel by the U.S. Department of Justice in 2002, the case of the U.S. semiconductors provides hard evidence for the relationship between cartels and and antidumping laws. Moreover, since the antidumping petition led to a suspension agreement rather than an actual duty, this case supports the literature that has assessed withdrawn antidumping petitions as an indicator of tacit collusion (Prusa, 1992; Zanardi, 2004b; Rutkowski, 2007). 
We observe similar characteristics in the case of the nitrile synthetic rubber cartel. Between 1996 and 2002, five multinational firms headquartered in the United States, Germany, Japan and Mexico operated a cartel in the nitrile synthetic rubber sector. Affecting an estimated 944 million USD of worldwide commerce, this global cartel was ultimately fined a total of 100 million USD (Connor, 2014b). Figure 1 presents the development of the logarithmised mean world import price of nitrile synthetic rubber between 1992 and 2014. In Figure 1, gray bars mark the initiation year of antidumping investigations, and the light blue background highlights that at least one antidumping duty for nitrile synthetic rubber is in force in a given year.

\section{Nitrile Synthetic Rubber}

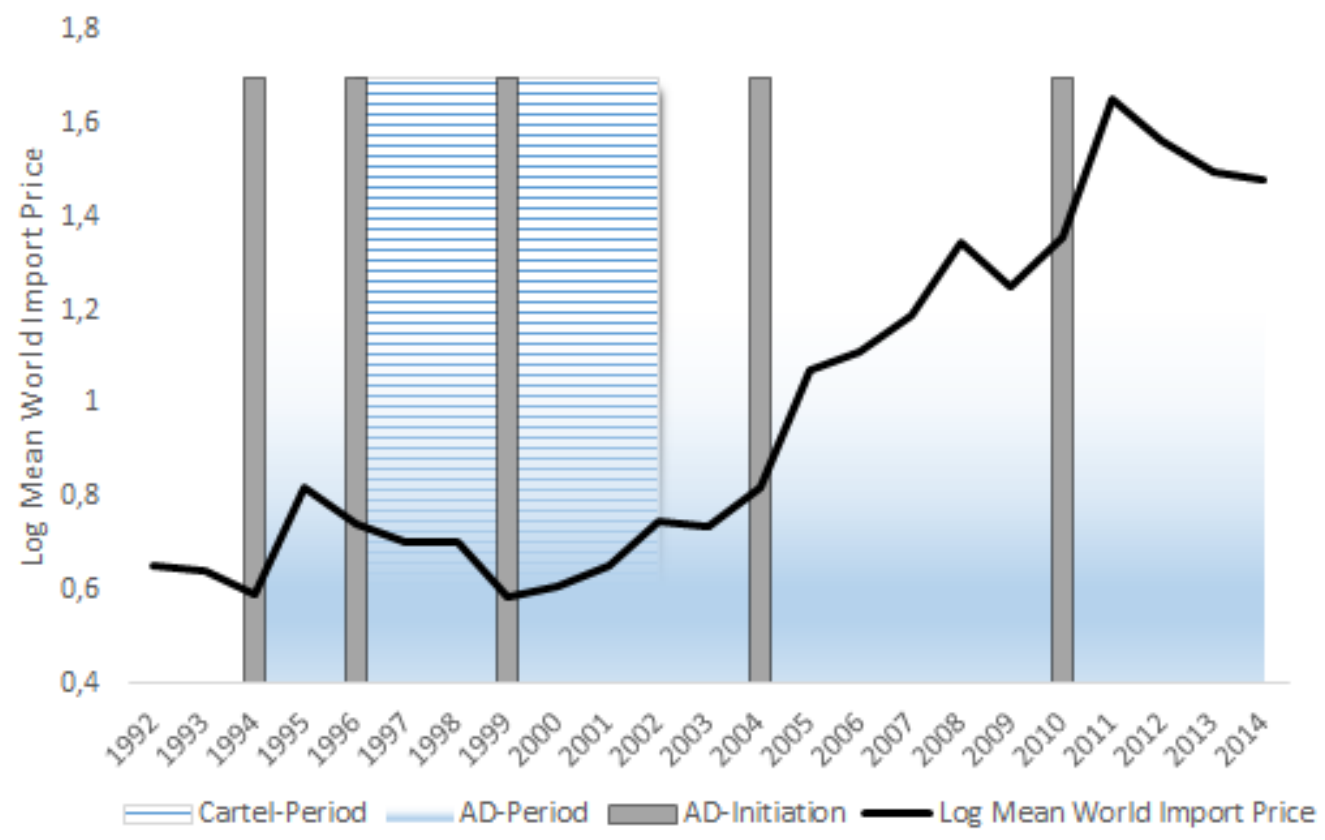

Figure 1: The logarithmised mean world import price for nitrile synthetic rubber (HS-Code: 400259) between 1992-2014. The cartel was caught for its anticompetitve behaviour for the period 1996-2002.

The link between the nitrile synthetic rubber cartel and antidumping investigations appeared first before the start of the cartel. In 1994, India launched an antidumping case against Japan, 
which later turned out to be part of the cartel. Figure 1 shows a spike in world import prices of nitrile synthetic rubber following the initiation of India's antidumping case against Japan. Further antidumping cases for nitrile synthetic rubber were initiated in 1997 and 1999 (both during the cartel period) as well as in 2004 and 2010 (both after the cartel period). As world import

prices increased with each initiation of new antidumping investigations after the cartel period, it is possible that a new cartel agreement was arranged with the help of antidumping laws. In any case, antitrust authorities did not find formal evidence for a cartel after 2002. Consistent with Irwin (1998), the example of the nitrile synthetic rubber cartel shows that antidumping cases could indeed function as a device to induce collusion in a global market.

\subsection{During the Cartel}

Existing cartels face the challenge to align defecting cartel members. Beyer (2010) discusses the case of the monosodium glutamate (MSG) cartel, where Japanese firm Ajinomoto successfully filed an antidumping complaint against its fellow Korean cartel partner. A similar pattern was observed in the lysine cartel, where the mere threat of an antidumping petition was enough for a defecting cartel member to comply with cartel rules (Harrington Jr et al., 2006, p. 64). Since in both cases antidumping has been used as a strategic tool to maintain cartel agreements, the initiation of an antidumping case could signal instability of an existing (yet undetected) cartel.

A second challenge to existing cartels provides the market entry of new competitiors. Since antidumping laws provide the power to target individual firms, undetected incumbent cartel industries can file antidumping petitions to create barriers to the market entry of new competitors. According to Zanardi (2004b), the likelihood for antidumping petitions to lead to the imposition of antidumping duties increases with the bargaining power or domestic importance of the petitioning industry.

Several instances for this scenario are documented in the literature. In the citric acid in- 
dustry, U.S. cartel members attempted twice to block the entry of Chinese firms to the U.S. market (Evenett et al., 2001, p. 1228). Partially successful was the U.S. ferrosilicon cartel whose petition led to the imposition of antidumping duties against Brazil, China, and other countries. However, after the United States International Trade Commission found out about the conspiracy, antidumping duties were reversed (Pierce Jr, 1999). In contrast, the PVC and LdPE (chemical industry) cartels successfully prevented entry of East European competitors into the EC market via antidumping protection (Messerlin, 1990, p. 477). Another example is the polyester staple fiber cartel, which prevented the entry of Korean and Taiwanese firms into the U.S. market (Reynolds, 2013, p. 416). A historical example provides the international steel cartel, which used antidumping duties in order to keep U.S. imports out of the South African market (Hexner, 1943; Staiger and Wolak, 1994). The examples imply that new market entrants are threatened by antidumping measures, leaving them to decide either to join the cartel or to stop exporting to cartelised markets. Thus the filing of antidumping petitions during the cartel period provides cartel firms with a tool to maintain cartel agreements.

To illustrate the power of antidumping cases during cartel activity, we add here the example of cathode ray tubes, which are used in television, computer and camera production. Between 1997 and 2007, 19 multinationals originating from Asia and Western Europe operated a global cartel in the cathode ray tubes industry. Affecting an estimated 82.5 billion USD of worldwide commerce, this global cartel was fined about 140 million USD in the United States, Korea and Japan (Connor, 2014b) and 1.5 billion EUR in the European Union (European Commission, 2012).

Figure 2 presents the development of the logarithmised mean world import price of cathode ray tubes between 1992 and 2014. In Figure 2, gray bars mark the initiation year of antidumping investigations, and the light blue background highlights that at least one antidumping duty for cathode ray tubes is in force in a given year. While cartel authorities found evidence for a cartel 


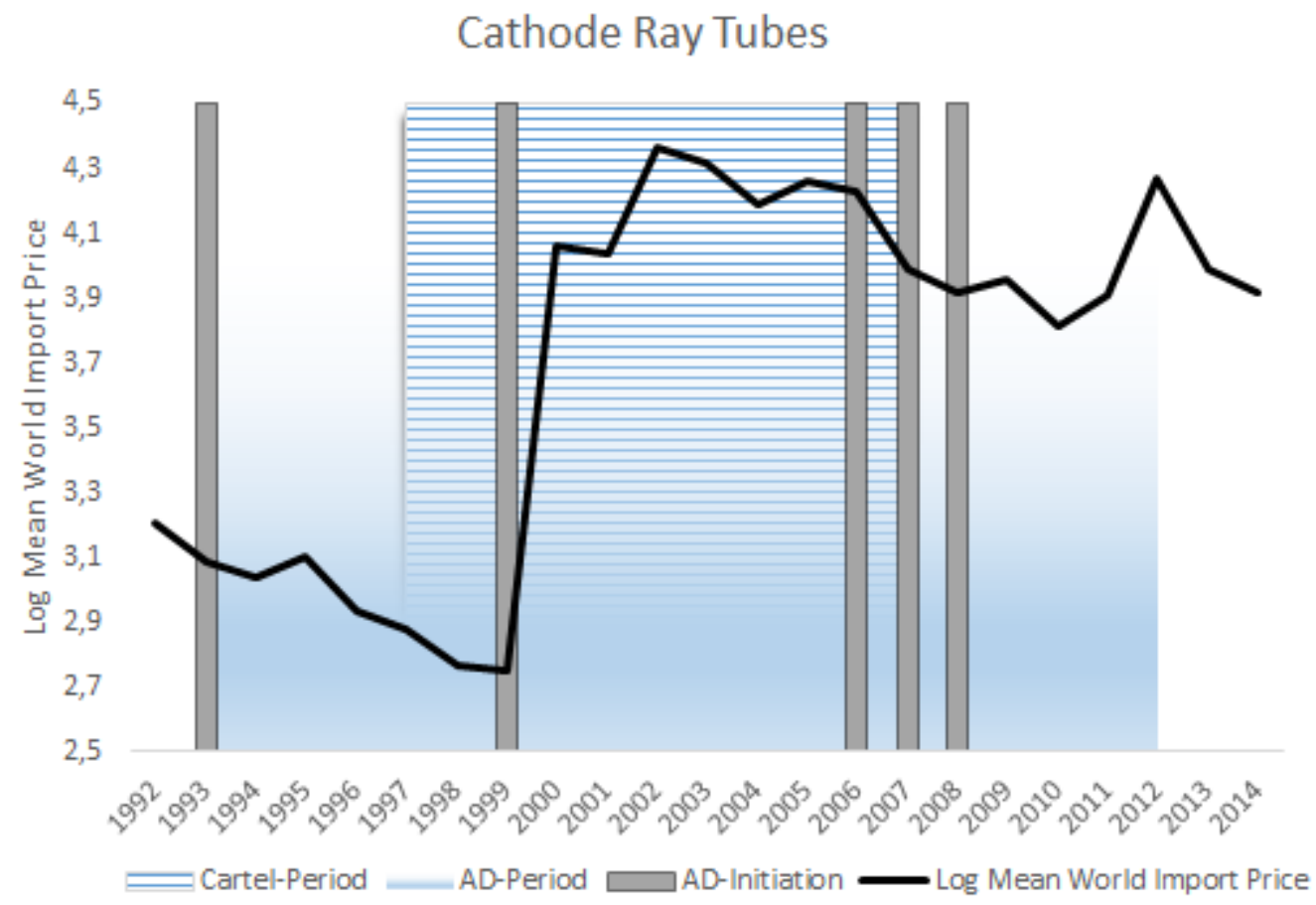

Figure 2: The logarithmised mean world import price for cathode ray tubes (HS-Code: 854011) between 1992-2014. The cartel was caught for its anticompetitve behaviour for the period 1997-2007.

start in 1997, Figure 2 illustrates that prices of cathode ray tubes only increased significantly in 1999-2000, which coincides with an antidumping case initiated by the EU against South Korea and India - both of which were later found to be cartel members. Thus it is very well possible that the antidumping case in the EU allowed the cathode ray tubes cartel not only to preserve collusion, but to enlarge the cartel by including the new entrants from South Korea and India.

\section{Data}

In order to assess empirically whether cartels systematically exploit antidumping laws we require information on twin antitrust and antidumping cases - that is, products that are subject to both antitrust and antidumping investigations. To the best of our knowledge, Messerlin (1990) 
is the only paper that linked antitrust and antidumping investigations, but only for cases in the European Commission in the 1980s. In the following we present the data sources and methodology that helps us to construct a twin dataset of global antidumping and antitrust cases.

As a starting point, we turn to the Global Anti-Dumping Database (GAD), which holds information on all antidumping cases filed in 33 countries between 1978 and 2015 (Bown, 2015). Next to all relevant dates concerning antidumping investigations (e.g. start of investigation, imposition date of antidumping duties, revocation dates) and outcomes (e.g. duties, withdrawals), GAD provides detailed 6-digit HS codes for each product listed in the legal documentation of each antidumping case. ${ }^{7}$ In addition, GAD informs about all domestic firms that filed an antidumping petition and all foreign firms accused in antidumping investigations.

Since we wish to map antidumping and antitrust cases based on a common identifier, we would ideally use an antitrust database similar to GAD, which should hold 6-digit HS codes. As such a cartel database is not yet available, we turn to the second best alternative, which is the Private International Cartels (PIC) dataset developed by Connor (2014b). ${ }^{8}$ As the largest known collection of legal and economic information on antitrust investigations, the PIC dataset covers 869 antitrust cases, with the earliest cartel start year in 1875 and the latest cartel end year in 2012. Besides detailed information on the duration and characteristics of cartels, the dataset provides the names of firms listed in the legal case documentation, and their country of origin. That is, the PIC dataset records the firm name and country listed in legal antitrust documents, and adds the country of the headquarter if the firm is a subsidiary of a multinational firm. Also available are estimates of the affected commerce and at least partial information on cartel fines.

The PIC dataset classifies cartels into three categories: domestic, international and global cartels. We focus here exclusively on global cartels. According to Connor (2014b, p. 51), these

\footnotetext{
${ }^{7}$ In some instances there are also 2-digit, 4-digit and 8-digit HS codes. We transform 8-digit HS codes into 6-digit HS codes. Eventually we can use only 6-digit HS codes, as this unit of observation allows us to match the antidumping data with the available trade data.

${ }^{8}$ The dataset was available at https://purr.purdue.edu/publications/2732/1, last accessed 11/11/2020.
} 
cartels were fined in legal antitrust investigations for fixing prices on at least two continents, which makes them most relevant to our assessment of the strategic use of antidumping. We exclude cartels that are in services, as there are no trade data for services available on such disaggregated level. Also, we drop those cartels that were active exclusively before 1992 due to the lack of reliable worldwide trade data. As a result, we obtain 61 global cartels. Figure A3 shows the share of countries involved in our set of global cartels, suggesting that the majority of cartel firms originate from the European Union, the United States and Japan.

Unfortunately, the PIC dataset does not contain any sort of codes on the products involved in antitrust investigations. We therefore made it our task to individually review each cartel and identify the relevant 6-digit HS codes by comparing product descriptions in the legal antitrust case documentations and descriptions of 6-digit HS codes on the UN's Comtrade website. In this process we complement the PIC dataset with summary court decisions and press releases. Where missing, we also added information on the firms involved in the cartels and on the fines received by the cartel participants.

The cathode ray tubes cartel discussed in the previous section provides an excellent example to illustrate how we identify the relevant 6-digit HS codes for each of the 61 global cartels. First, we read the product description provided in the legal antitrust document of the European Commission's Directorate-General for Competition, with CASE-ID “AT.39437 -TV and computer monitor tubes". 9 In this legal document the EC informs that there are two types of cathode ray tubes - colour display tubes used in computer monitors and colour picture tubes used for colour televisions. According to the legal case documentation, these distinct versions of cathode ray tubes cannot be interchanged because television and computer monitors require specialised and different resolution.

Next, we turn to the UN's Comtrade website to search and review the relevant 4-digit HS

\footnotetext{
${ }^{9}$ The legal documentation for the European Commission's antitrust investigations is available at https://ec.europa.eu/competition/elojade/isef, last accessed 11/11/2020.
} 
code, which is 8540 . The description for this 4-digit HS code is as follows: "Thermionic, cold cathode or photo-cathode valves and tubes (for example, vacuum or vapour or gas filled valves and tubes, mercury arc rectifying valves and tubes, cathode-ray tubes, television camera tubes)." Since the term "cathode ray tube" is part of this description among other subjects (such as television camera tubes), we decided to read through the description of all 6-digit HS codes listed below the 4-digit HS code 8540 .

Figure A1 shows the descriptions of all 6-digit HS codes listed below the 4-digit HS code 8540. After assessing these descriptions, we identify and collect codes 854011, 854012 and 854060 for our dataset since their description is directly related to the product listed in the EC's antitrust investigation. In contrast, codes such as 854072 refer to microwave tubes, which are clearly not relevant to the cathode ray tubes cartel. We are therefore sure that the 6-digit HS code is the level of detail we require to identify twin antitrust and antidumping cases. We also repeat the exercise of reviewing HS codes for each HS vintage, because codes are updated, merged, abandoned or added as the evolution of the Comtrade database proceeds.

Based on the 6-digit HS code, we are able to merge our dataset of global cartels to the Global Anti-Dumping Database. In our twin antitrust and antidumping dataset we test the validity of our approach by comparing the product description variables originating from the PIC and the GAD dataset. For example, we notice that AD-Case IND-AD-189, which refers to an antidumping case for Paracetamol in India, includes product codes 854511 and 854519 , both of which refer to Graphite Electrodes. As this antidumping case is unlikely related to the graphite electrodes cartel, we exclude AD-Case IND-AD-189 from our twin dataset of antitrust and antidumping cases. However, we keep both product codes as they match a number of antidumping cases in graphite electrodes to the graphite electrodes cartel.

Table 1 summarises the matches that we obtain after consolidating our final twin dataset of antitrust and antidumping cases. Out of the total 61 global cartels that were active at least 
Table 1: Antitrust and Antidumping Descriptive Statistics

(a) Panel A: Number of cartels and cartel products with at least one antidumping case.

\begin{tabular}{|c|c|c|c|}
\hline & Matched with AD & No match with AD & Total \\
\hline Number of cartel cases & $43(70 \%)$ & $18(30 \%)$ & $61(100 \%)$ \\
\hline Number of cartel products & $79(52 \%)$ & $74(48 \%)$ & $153(100 \%)$ \\
\hline
\end{tabular}

(b) Panel B: Number of products with at least one antidumping case.

\begin{tabular}{|l|c|c|c|}
\hline & Involved in AD & Not involved in AD & Total \\
\hline Number of products & $1838(33 \%)$ & $3811(67 \%)$ & $5649(100 \%)$ \\
\hline
\end{tabular}

until 1992, we find that 43 or $70 \%$ are matched to at least one antidumping investigation between 1992 and 2014. This figure reads very well in response to Messerlin (1990). Only for the European Commission's 1980-1987 antitrust cases, Messerlin (1990) reports that roughly one quarter was matched to antidumping cases, with the expectation to see this figure increase after 1990. Our data confirm this hypothesis. Table 1 also reports the number and share of products in the Comtrade database that are matched to antidumping investigations, and to both antitrust and antidumping investigations. Out of 153 cartel products, 79 or $52 \%$ are matched to at least one antidumping investigation. Since only 1838 out of all 5649 (33\%) products in the Comtrade database are matched to at least one antidumping investigation, it can be concluded that antidumping investigations are much more frequent in cartel products than in non-cartel products.

Figure A4 shows the share of countries involved in any of the 43 global cartels that are matched to at least one antidumping investigation. The distribution of countries in the twin dataset is very similar to the distribution of countries in the entire antitrust dataset (Figure A3), which suggests that the sample of cartels in the twin dataset is comparable to the full sample of cartels in the antitrust dataset. As our sample includes only global cartels, it is also of little surprise that the European Union, the United States and Japan together comprise $85 \%$ of the 
countries in the cartel dataset. These countries are home to the headquarters of the largest multinational firms in the world.

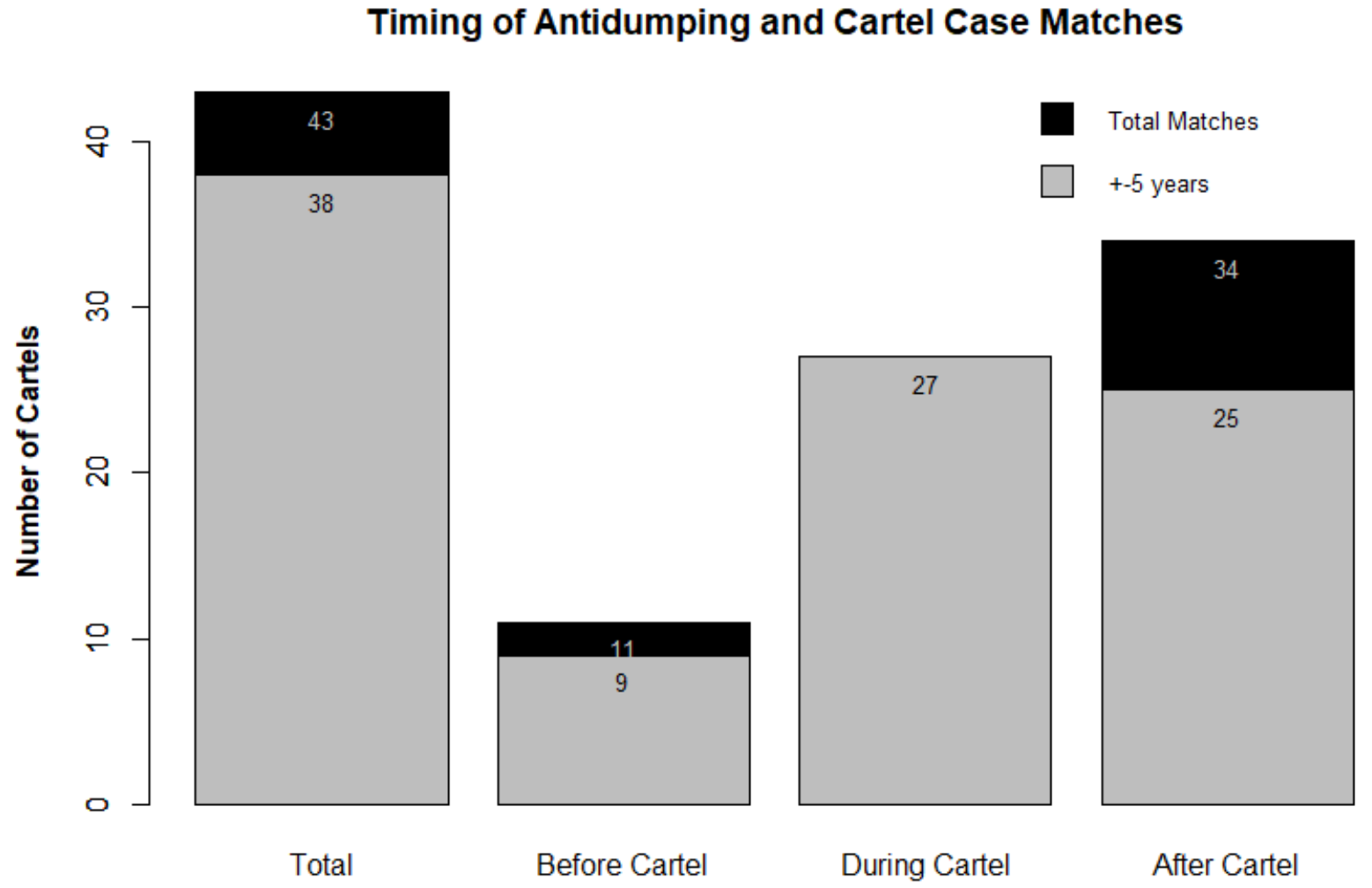

Figure 3: Antitrust and antidumping case matches relative to the cartel period. The figure shows the number of antitrust cases that are matched to at least one antidumping investigation relative to the cartel period.

Figure 3 visualises the matches between antitrust and antidumping cases relative to the cartel period. Comparing the first black and grey bars in Figure 3, it appears that 38 out of the 43 cartels are linked to at least one antidumping case either during the cartel period, up to five years before the cartel start or up to five years after the cartel end. This figure underlines the timely overlap between antitrust and antidumping investigations in the same products. Moreover, Figure 3 highlights that 27 out of the 43 cartels are linked to at least one antidumping investigation 
while these cartels were active. If we only consider matches between antitrust and antidumping cases that occur up to five years before the cartel, during the cartel period or up to five years after the cartel, then we can conclude that the majority of twin antitrust and antidumping cases occur during the cartel period. This interpretation is also true if we consider matches between antitrust and antidumping cases based on products, visualised by Figure A2 in the appendix.

Figure A5 shows the share of countries that initiated antidumping investigations in the entire antidumping dataset, and Figure A6 shows the share of countries that initiated antidumping investigations in the twin antitrust and antidumping dataset. In the entire antidumping dataset, the most prominent users of antidumping are the United States (28\%), India (9\%), the European Union (9\%), Canada (8\%), Argentina (7\%), Russia (5\%), Mexiko (5\%), Argentina (5\%) and Brazil (4\%). The pattern is in line with Bown (2015), who discusses the increasing use of antidumping by newly industrialised countries. In the twin dataset of antidumping and antitrust cases, the most prominent user of antidumping is India (20\%), the European Union (15\%), the United States (14\%), Argentina (10\%), South Africa (7\%), Brazil (5\%), Australia (4\%), China (4\%) and Mexico (4\%). In comparison to the entire antidumping dataset, it can therefore be concluded that the use of antidumping is more prominent in cartel industries in India and the European Union, but less prominent in the United States.

Figure A7 shows the share of countries targeted in antidumping investigations in the entire antidumping dataset, and Figure A8 shows the share of countries targeted in antidumping investigations in the twin antitrust and antidumping dataset. In the entire antidumping dataset, the most prominent targets of antidumping are China (19\%), South Korea (6\%), Taiwan (5\%), Japan (4\%), Brazil (4\%), the United States (4\%), India (3\%), Indonesia (3\%) and Germany (3\%). In the twin dataset of antitrust and antidumping cases, the most prominent target of antidumping is China (19\%), South Korea (9\%), the United States (9\%), Germany (7\%), Brazil (6\%), Italy (5\%), Japan (4\%), Malaysia (4\%) and India (3\%). In comparison to the entire an- 
tidumping dataset, it can be concluded that high-technology countries such as South Korea, the United States and Germany are more prominent targets of antidumping in cartel industries.

\section{Estimation Strategy}

Our empirical research comes as a response to the theoretical literature discussed in Section 2 and as a test of the mechanisms reviewed in Section 3. First, we test empirically whether antidumping has a trade and price altering impact by stalling competition through duties (Staiger and Wolak, 1992; Veugelers and Vandenbussche, 1999) or by mere threat (Prusa, 1992; Zanardi, 2004b). Therefore, our empirical strategy should account both for the impact of antidumping duties and for the impact of withdrawn antidumping petitions.

Second, we test the hypotheses that antidumping can lead to international cartels as well as be used by cartels to maintain collusive prices during its activity, as implied by theoretical models and case-study based mechanisms of Section 3. We test, whether cartel-prone industries use antidumping to successfully induce collusive price and quantity outcomes as predicted by Prusa (1992), Veugelers and Vandenbussche (1999), and Zanardi (2004b), and whether antidumping is used as a disciplining device during the cartel activity as found by Staiger and Wolak (1989, 1992).

To test these hypotheses, our empirical strategy identifies whether global cartels use antidumping as a collusive device to manipulate import prices and quantities. The identification assesses the differential impact of antidumping in products that have been in global cartels at some point in the sample period, relative to those products that have never been linked to global cartels or antidumping investigations. In Section 6.2 we also assess different outcomes of antidumping investigations, such as antidumping cases that are withdrawn by the petitioning industry.

Our baseline regression estimates whether the world import price of product $x$ is different 
in years $t$, where product $x$ is either part of an active cartel, or where product $x$ is subject to at least one ${ }^{10}$ antidumping investigation. ${ }^{11}$ In addition, our baseline regression estimates whether the world import price of product $x$ is different in years $t$, when product $x$ is a cartel-prone ${ }^{12}$ product that is either subject to at least one antidumping investigation before, during or after the legally proven cartel period. ${ }^{13}$ This set of coefficients should inform about the timing of antidumping cases relative to the activity of globally active cartels in the same product.

In order to capture the full extent of our sample of global cartels, we treat the world as a single market by focussing on world import prices. As a measure of the world import price we use three alternative specifications, all of which source from all bilaterally traded quantities and values available in the Comtrade dataset between 1992 and 2014. First, we calculate the world import price based on the mean of all bilaterally traded quantities and values. Second, we calculate the world import price based on the median of all bilaterally traded quantities and values. Third, we calculate the trade-weighted world import price based on the aggregate of all bilaterally traded quantities and values. To be precise, the three dependent variables of interest are the logarithmised mean world import price, the logarithmised median world import price and the logarithmised trade-weighted world import price of each product at 6-digit HS classification that we observe for each year between 1992 to 2014. Our unit of observation is therefore the Product - Year and the sample includes all products at 6-digit HS classification reported in the UN Comtrade database.

\footnotetext{
${ }^{10}$ In Table A1 we alternatively estimate the effect on world import prices when product $x$ is subject to more than one antidumping investigation in year $t$.

${ }^{11}$ Note that we define an antidumping investigation to be the period between the initiation of legal antitrust investigation and until the revokation of antidumping duties.

${ }^{12}$ This wording is purposefully cautious: we do not claim that these products have not been cartelised but rather that our strict matching procedure did not link them to cartels or that cartels in those products have not been identified at all.

${ }^{13}$ In Table A2 we show that our results hold when we reduce the matches between antidumping and antitrust cases so that we consider only antidumping cases that are initiated up to five years before the legally proven cartel start and up to five years after the legally proven cartel end.
} 
The baseline regression is as follows:

$$
\begin{aligned}
\operatorname{lnPrice}_{x t}= & \alpha_{0} A D_{x t}+\alpha_{1} A D_{x t} \mathbb{1}_{\text {CartelProduct }}(\text { AD BeforeCartel }) \\
& +\alpha_{2} A D_{x t} \mathbb{1}_{\text {CartelProduct }}(\text { ADDuringCartel }) \\
& +\alpha_{3} A D_{x t} \mathbb{1}_{\text {CartelProduct }}(\text { ADAfterCartel }) \\
& +\gamma \mathbb{1}_{\text {CartelPeriod }}+\eta_{x}+\delta_{t}+\epsilon_{x t}
\end{aligned}
$$

where the dependent variable lnPrice $_{x t}$ is the logarithmised world import price of product $x$ in year $t$, for any of the three specifications of the world import price introduced above. $A D_{x t}$ is a dummy that turns 1 if product $x$ is involved in at least one antidumping investigation in year $t .{ }^{14}$ CartelProduct $x$ is a dummy that classifies all products that are subject to at least one antitrust investigation in the sample period. The vector Timing ${ }^{T}=($ Before, During, After $)$ refers to the timing of antidumping investigations relative to legally proven cartel periods. That is, antidumping investigations may be initiated before, during or after the legally proven cartel

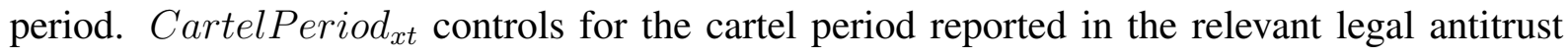
documents. Finally, $\eta_{x}$ controls for all product-specific fixed-effects and $\delta_{t}$ controls for all timespecific fixed effects.

In contrast to our empirical strategy, much of the cartel literature studies the impact of individual cartel cases in single countries (Irwin, 1998; Harrington Jr et al., 2006; Beyer, 2010). Yet the anticompetitive behaviour of multinational firms likely affects prices beyond the jurisdiction of a single antitrust authority. The best known empirical study on the trade effect of international cartels is Levenstein et al. (2015), who estimate a gravity model and do not find a significant impact of seven international cartels on bilateral trade. Similarly, Agnosteva (2016) reports that only $50 \%$ of the 170 international cartels in her dataset significantly affected bilateral trade. Although we have also collected a large dataset of firms that were sanctioned for their anticompetitive behaviour on at least two continents, we are conservative in the use of

\footnotetext{
${ }^{14}$ Since 6-digit-products can be part of multiple antidumping investigations, in an alternative regression reported in Table A1 we add an additional dummy that accounts for multiple antidumping investigations in the same product.
} 
these data. In fact, due to the complexity of multinational firms it is likely that the firms listed in legal antitrust investigations only show the tip of an iceberg. For instance, Evenett et al. (2001, p. 1229) mention that only a subsidiary of a Japanese multinational was sanctioned in the U.S. antitrust case in graphite electrodes. Moreover, as legal antitrust investigations require concise documentation and data as evidence of collusion, it is likely that much of the anticompetitive behaviour of multinational firms and cartels goes unnoticed.

\section{Results}

We discuss our empirical results in three parts. Section 6.1 presents the baseline import price impact of antidumping in cartel products. In this section, variable $A D$ refers to any year $t$ where product $x$ is subject to at least one antidumping case. In Section 6.2 we refine our approach to

distinguish antidumping cases that lead to an antidumping duty, those that were withdrawn by the petitioning industry, and those that did not result in duties due to other reasons. In Section 6.3 we discuss regression results for import quantities.

\subsection{Baseline Results}

Table 2 presents the result of our baseline estimation. First, during legally proven cartel periods of globally active cartels, the world import price of the relevant cartel products increases relative to the world import price of non-cartel products. The coefficient we estimate here suggests that world import prices increase by 9 to $12 \%$ during the cartel period. This finding shows that globally active cartels are powerful enough to concert prices in a global environment. This highlights the need for antitrust authorities to cooperate at a global level in order to capture the true damage caused by global cartels (see Hoekman et al., 1997).

Second, in years where a product is subject to at least one antidumping case the world im- 
port price of that product decreases on, average, by 5 to $10 \%{ }^{15}$ The coefficient we estimate for the antidumping period is highly statistically significant and robust to all alternative calculations of the world import price. Given that antidumping investigations only concern bilateral affairs, their impact on world import prices is ex-ante ambiguous. On the one hand, firms hit by antidumping investigation have an incentive to increase export prices to avoid imposition of duties (Prusa, 1994, 2001). On the other hand, these firms might reduce their export prices in other markets as they deflect their exports to these markets (Bown and Crowley, 2007).

\footnotetext{
${ }^{15} \mathrm{We}$ also estimate whether it makes a difference when a product is subject to more than antidumping investigation in the same year in Table A1. The results are similar, with involvement in more than one antidumping case leading to larger reductions in world import prices.
} 
Table 2: Baseline Regression.

\begin{tabular}{|c|c|c|c|}
\hline & $\begin{array}{c}(1) \\
\text { Log Mean Price }\end{array}$ & $\begin{array}{c}(2) \\
\text { Log Median Price }\end{array}$ & $\begin{array}{c}(3) \\
\text { Log Trade-Weighted Price }\end{array}$ \\
\hline Cartel Period $^{1}$ & $\begin{array}{l}0.0912^{* *} \\
(2.50)\end{array}$ & $\begin{array}{l}0.121^{* * *} \\
(2.64)\end{array}$ & $\begin{array}{l}-0.0377 \\
(-0.47)\end{array}$ \\
\hline $\mathrm{AD}^{2}$ & $\begin{array}{c}-0.0568^{* * *} \\
(-3.57)\end{array}$ & $\begin{array}{c}-0.102^{* * *} \\
(-4.75)\end{array}$ & $\begin{array}{c}-0.101^{* * *} \\
(-4.64)\end{array}$ \\
\hline AD Before Cartel ${ }^{3}$ & $\begin{array}{l}0.129^{* *} \\
(2.09)\end{array}$ & $\begin{array}{l}0.201^{* * *} \\
(2.84)\end{array}$ & $\begin{array}{c}0.416^{* * *} \\
(2.61)\end{array}$ \\
\hline AD During Cartel ${ }^{4}$ & $\begin{array}{l}0.175^{* *} \\
(2.20)\end{array}$ & $\begin{array}{l}0.159^{*} \\
(1.79)\end{array}$ & $\begin{array}{l}0.271^{*} \\
(1.78)\end{array}$ \\
\hline AD After Cartel $^{5}$ & $\begin{array}{l}-0.0561 \\
(-1.28)\end{array}$ & $\begin{array}{l}-0.133^{* *} \\
(-2.53)\end{array}$ & $\begin{array}{l}-0.144^{*} \\
(-1.70)\end{array}$ \\
\hline $\begin{array}{l}\text { Observations } \\
\text { Products } \\
\text { Product-FE } \\
\text { Year-FE }\end{array}$ & $\begin{array}{c}116,153 \\
5,649 \\
\text { Yes } \\
\text { Yes }\end{array}$ & $\begin{array}{c}116,153 \\
5,649 \\
\text { Yes } \\
\text { Yes }\end{array}$ & $\begin{array}{c}116,157 \\
5,649 \\
\text { Yes } \\
\text { Yes }\end{array}$ \\
\hline \multicolumn{4}{|c|}{$\begin{array}{l}t \text { statistics in parentheses } \\
{ }^{*} p<0.10,{ }^{* *} p<0.05,{ }^{* * *} p<0.01 \text {, based on robust standard errors clustered at product level. } \\
{ }^{1} \text { Dummy that is } 1 \text { in years where a product is part of an antitrust case with firms from at least two continents. } \\
{ }^{2} \text { Dummy that is } 1 \text { in years where a product is subject to at least one AD case. } \\
{ }^{3} \text { Dummy that is } 1 \text { in years where a cartel product is included in at least one AD case, before the cartel start. } \\
4 \text { Dummy that is } 1 \text { in years where a cartel product is included in at least one AD case, during the cartel period. } \\
{ }^{5} \text { Dummy that is } 1 \text { in years where a cartel product is included in at least one AD case, after the cartel end. }\end{array}$} \\
\hline
\end{tabular}

Third, our results suggest that cartels take advantage of antidumping strategically as antidumping cases have very different effects on world import prices when they involve cartel products. We estimate that antidumping cases in cartel products before the cartel start lead to a world import price increase of 12 to $41 \%{ }^{16}$ This result is consistent the hypothesis that cartel-prone industries can reach collusive outcomes through antidumping cases, as well as the

\footnotetext{
${ }^{16}$ Table A2 shows that our results hold when we consider only antidumping cases initiated up to five years before the cartel start and up to five years after the cartel end.
} 
examples presented in Section 3.

Antidumping cases initiated during the cartel period lead to an additional increase of world import prices by 15 to $27 \%$, controlling for the price impact of the cartel period. Again, this finding is statistically significant and robust to all specifications of the world import price. One has to note that antitrust authorities require hard evidence to prove the initiation and might use a conservative start-date in the cartel investigation. In this case, our finding for the impact before the cartel start might capture an earlier start of a cartel. However the positive price impact of antidumping during the cartel activity is robust to such concerns as we control for the impact of the cartel period.

Interestingly, antidumping investigations initiated after the breakdown of global cartels are associated with declines in world import prices, which might signal that the anticompetitive use of antidumping laws itself is not sufficient for cartels to reinstate collusion. For instance, the breakdown of cartels might also be due to technological developments or the secular decline of certain industries, such as colour tube televisions.

\subsection{Multiple Outcomes of Antidumping Investigations}

In the baseline setting, we define $A D$ as a dummy variable that is 1 for any year where at least one antidumping case for product $x$ is initiated or where at least one antidumping measure for the same product is in force. Since not all antidumping investigations lead to an antidumping duty, we refine the estimation strategy to distinguish for the antidumping investigations that do not lead to an antidumping duty. This modification allows to connect our results to the literature that studies the withdrawal of antidumping cases as a sign of tacit collusion (Prusa, 1992; Zanardi, 2004b; Rutkowski, 2007).

Specifically, $A D$ Duty is a dummy that turns 1 in years between the initiation of an antidumping investigation and until the eventual revocation of antidumping duties. AD Withdrawn 
Table 3: Five-year lag from the initiation of Antidumping Cases.

\begin{tabular}{|c|c|c|c|c|c|}
\hline & & & $\begin{array}{c}(1) \\
\text { Log Mean Price }\end{array}$ & $\begin{array}{c}(2) \\
\text { Log Median Price }\end{array}$ & $\begin{array}{c}(3) \\
\text { Log Trade-Weighted Price }\end{array}$ \\
\hline \multicolumn{3}{|l|}{ Cartel Period } & $\begin{array}{c}0.102^{* * *} \\
(2.89)\end{array}$ & $\begin{array}{c}0.133^{* * *} \\
(2.99)\end{array}$ & $\begin{array}{c}-0.0347 \\
(-0.42)\end{array}$ \\
\hline \multirow[t]{4}{*}{ AD Duty ${ }^{1}$} & & & $\begin{array}{c}-0.0592^{* * *} \\
(-3.68)\end{array}$ & $\begin{array}{c}-0.107^{* * *} \\
(-4.99)\end{array}$ & $\begin{array}{c}-0.0993^{* * *} \\
(-4.48)\end{array}$ \\
\hline & $x$ & Before Cartel & $\begin{array}{c}0.130^{* *} \\
(2.19)\end{array}$ & $\begin{array}{c}0.193^{* * *} \\
(2.74)\end{array}$ & $\begin{array}{c}0.459^{* * *} \\
(3.33)\end{array}$ \\
\hline & $x$ & During Cartel & $\begin{array}{l}0.231^{* * *} \\
(2.70)\end{array}$ & $\begin{array}{c}0.227^{* *} \\
(2.42)\end{array}$ & $\begin{array}{l}0.291^{*} \\
(1.84)\end{array}$ \\
\hline & $x$ & After Cartel & $\begin{array}{c}-0.0534 \\
(-1.19)\end{array}$ & $\begin{array}{c}-0.115^{* *} \\
(-2.11)\end{array}$ & $\begin{array}{c}-0.144^{*} \\
(-1.92)\end{array}$ \\
\hline \multicolumn{3}{|c|}{ AD Withdrawn ${ }^{2}$} & $\begin{array}{c}-0.122^{* * *} \\
(-3.35)\end{array}$ & $\begin{array}{c}-0.182^{* * *} \\
(-3.73)\end{array}$ & $\begin{array}{c}-0.112^{* * *} \\
(-2.74)\end{array}$ \\
\hline & $x$ & Before Cartel & - & - & - \\
\hline & $x$ & During Cartel & $\begin{array}{c}0.264^{* *} \\
(2.04)\end{array}$ & $\begin{array}{l}0.323 \\
(1.62)\end{array}$ & $\begin{array}{c}0.471^{* * *} \\
(3.31)\end{array}$ \\
\hline & $x$ & After Cartel & $\begin{array}{c}0.0836 \\
(1.61)\end{array}$ & $\begin{array}{c}0.144^{* *} \\
(2.24)\end{array}$ & $\begin{array}{c}0.0837 \\
(1.28)\end{array}$ \\
\hline \multirow[t]{4}{*}{ AD Other ${ }^{3}$} & & & $\begin{array}{c}0.0260 \\
(1.60)\end{array}$ & $\begin{array}{c}0.0518^{* *} \\
(2.35)\end{array}$ & $\begin{array}{c}0.00489 \\
(0.25)\end{array}$ \\
\hline & $x$ & Before Cartel & $\begin{array}{l}-0.0407 \\
(-0.52)\end{array}$ & $\begin{array}{l}0.0114 \\
(0.11)\end{array}$ & $\begin{array}{l}-0.302 \\
(-0.81)\end{array}$ \\
\hline & $x$ & During Cartel & $\begin{array}{c}-0.250^{* * *} \\
(-3.74)\end{array}$ & $\begin{array}{c}-0.306^{* * *} \\
(-3.33)\end{array}$ & $\begin{array}{l}-0.117 \\
(-1.24)\end{array}$ \\
\hline & $x$ & After Cartel & $\begin{array}{l}-0.0454 \\
(-1.06)\end{array}$ & $\begin{array}{c}-0.129^{* *} \\
(-2.48)\end{array}$ & $\begin{array}{l}-0.0389 \\
(-0.56)\end{array}$ \\
\hline Observations & & & 116,153 & 116,153 & 116,157 \\
\hline Products & & & 5,649 & 5,649 & 5,649 \\
\hline Product-FE & & & Yes & Yes & Yes \\
\hline Year-FE & & & Yes & Yes & Yes \\
\hline
\end{tabular}

Notes: $t$ statistics in parentheses

${ }^{*} p<0.10,{ }^{* *} p<0.05,{ }^{* * *} p<0.01$, based on robust standard errors clustered at product level.

${ }^{1}$ Antidumping investigations that lead to antidumping duties.

${ }^{2}$ Antidumping investigations withdrawn at the request of the domestic industry.

${ }^{3}$ Antidumping investigations that did not result in imposition of antidumping duties for other reasons. 
is a dummy that turns 1 for the initiation year and the following four years of an antidumping case that is withdrawn by the petitioning industry. This is done to capture the potential anticompetitive effect of withdrawn cases. AD Other is a dummy that turns 1 for the initiation year and the following four years of an antidumping case that does not lead to an antidumping duty for other reasons, for instance due to insufficient evidence of dumping.

Table 3 presents the results. First, we look at antidumping cases that eventually lead to a duty. Antidumping measures are associated with decline of world import prices by 5 to $10 \%$. Cartel-related antidumping that eventually leads to an antidumping duty and initiated before the cartel start, increases the world import price of that product by additional 13 to $45 \%$. Similarly, antidumping initiated during the cartel period is associated with a world import price increase by 23 to $29 \%$, controlling for the price effect of the cartel period. Again these findings confirm the baseline results in Table 2.

Second, we look at antidumping cases that were withdrawn by the domestic industry that filed the antidumping petition ( $A D$ Withdrawn). Withdrawn antidumping cases are associated with decline of world import prices by 11 to $18 \%$ in the five years following the initiation. An antidumping case withdrawn by the petitioning industry during the cartel period is associated with an increase in world import prices of the affected product by additional 26 to $47 \% .{ }^{17}$ In line with Prusa (1992) and Zanardi (2004b), this coefficient demonstrates anticompetitive use of withdrawn antidumping cases.

Third, we provide estimates for the impact of antidumping cases that do not lead to antidumping duties due to reasons, other than industry-withdrawn petitions, e.g., small import market share of investigated imports or insufficient evidence of dumping (AD Other). Antidumping cases in this category do not have a robust statistically significant effect on world import prices in the five years following the initiation. Indeed, if antidumping authorities find,

\footnotetext{
${ }^{17}$ There are no industry-withdrawn antidumping cases initiated before the cartel start.
} 
for example, that there was no evidence of dumping, then it is no surprise that there are no significant price effects at the global level. Similarly, antidumping in cartel products that does not lead to a duty and not industry-withdrawn has no significant world import price impact except when initiated during cartel periods. Antidumping cases initiated during cartel period are associated with world import prices decline by 25 to $30 \%$. This result is somewhat surprising, as we also find a corresponding increase in import quantities (see subsection 6.3 below).

Overall, supporting the theoretical predictions, cartel-related antidumping that either leads to duties or is withdrawn by the petitioning industry is associated with increases in world import prices relative to antidumping in other products. And consistent with the model predictions as well, this anticompetitive effect is present in cases initiated before and during cartel activity, controlling for cartel period and product fixed effects.

\subsection{Traded Quantities}

To this point we have only focused on world import prices. As firms operate by setting prices and quantities, in this subsection we look at the import quantities. We use the same specification as in Section 6.2 to assess the impact of antidumping in global cartels on world import quantities (Table 4).

Results for quantities in Table 4 are consistent with the price effects in Table A2. First, world import quantities decline by 9 to $11 \%$ during the cartel period of global cartels. Thus

globally active cartels affect world import prices by reducing import quantity and increasing import prices. Second, consistent with declining price effects, antidumping activity leading to duties or industry-withdrawn, is associated with increasing world import quantities (by 10 to $25 \%)$ 
Table 4: Five-year lag from the initiation of Antidumping Cases: Quantity.

\begin{tabular}{|c|c|c|c|c|c|}
\hline & & & $\begin{array}{c}(1) \\
\text { Log Mean Quantity }\end{array}$ & $\begin{array}{c}(2) \\
\text { Log Median Quantity }\end{array}$ & $\begin{array}{c}\text { (3) } \\
\text { Log Trade-Weighted Quantity }\end{array}$ \\
\hline Cartel Period & & & $\begin{array}{c}-0.0918^{* *} \\
(-2.42)\end{array}$ & $\begin{array}{l}-0.116^{* *} \\
(-2.55)\end{array}$ & $\begin{array}{l}-0.0201 \\
(-0.20)\end{array}$ \\
\hline \multirow[t]{4}{*}{ AD Duty ${ }^{1}$} & & & $\begin{array}{l}0.103^{* * *} \\
(6.55)\end{array}$ & $\begin{array}{l}0.151^{* * *} \\
(7.71)\end{array}$ & $\begin{array}{c}0.243^{* * *} \\
(7.21)\end{array}$ \\
\hline & $\times$ & Before Cartel & $\begin{array}{l}-0.0359 \\
(-0.21)\end{array}$ & $\begin{array}{c}-0.0410 \\
(-0.19)\end{array}$ & $\begin{array}{l}-0.396 \\
(-1.40)\end{array}$ \\
\hline & $\times$ & During Cartel & $\begin{array}{l}-0.235^{* *} \\
(-2.36)\end{array}$ & $\begin{array}{l}-0.324^{* *} \\
(-2.50)\end{array}$ & $\begin{array}{l}-0.369^{* *} \\
(-2.40)\end{array}$ \\
\hline & $\times$ & After Cartel & $\begin{array}{c}0.00560 \\
(0.09)\end{array}$ & $\begin{array}{l}0.0117 \\
(0.13)\end{array}$ & $\begin{array}{l}0.166 \\
(1.64)\end{array}$ \\
\hline \multirow[t]{4}{*}{ AD Withdra } & & & $\begin{array}{l}0.146^{* * *} \\
(3.74)\end{array}$ & $\begin{array}{l}0.170^{* * *} \\
(3.43)\end{array}$ & $\begin{array}{l}0.151^{* * *} \\
(2.72)\end{array}$ \\
\hline & $\times$ & Before Cartel & - & - & - \\
\hline & $\times$ & During Cartel & $\begin{array}{l}-0.342^{* *} \\
(-2.23)\end{array}$ & $\begin{array}{l}-0.479^{* *} \\
(-1.98)\end{array}$ & $\begin{array}{c}-0.726^{* * *} \\
(-7.13)\end{array}$ \\
\hline & $x$ & After Cartel & $\begin{array}{l}0.101 \\
(1.58)\end{array}$ & $\begin{array}{l}0.101 \\
(1.58)\end{array}$ & $\begin{array}{l}-0.166^{*} \\
(-1.95)\end{array}$ \\
\hline \multirow[t]{4}{*}{ AD Other ${ }^{3}$} & & & $\begin{array}{c}-0.000780 \\
(-0.04)\end{array}$ & $\begin{array}{c}-0.0275 \\
(-1.26)\end{array}$ & $\begin{array}{c}0.0340 \\
(1.19)\end{array}$ \\
\hline & $x$ & Before Cartel & $\begin{array}{c}-0.0693 \\
(-0.49)\end{array}$ & $\begin{array}{l}-0.210 \\
(-1.25)\end{array}$ & $\begin{array}{c}-0.0143 \\
(-0.03)\end{array}$ \\
\hline & $x$ & During Cartel & $\begin{array}{l}0.145^{*} \\
(1.69)\end{array}$ & $\begin{array}{l}0.195^{*} \\
(1.77)\end{array}$ & $\begin{array}{l}0.0235 \\
(0.21)\end{array}$ \\
\hline & $\times$ & After Cartel & $\begin{array}{l}0.0852 \\
(1.40)\end{array}$ & $\begin{array}{l}0.169^{* *} \\
(2.36)\end{array}$ & $\begin{array}{l}0.115 \\
(1.16)\end{array}$ \\
\hline Observations & & & 116,153 & 116,153 & 116,157 \\
\hline Products & & & 5,649 & 5,649 & 5,649 \\
\hline Product-FE & & & Yes & Yes & Yes \\
\hline Year-FE & & & Yes & Yes & Yes \\
\hline $\begin{array}{l}t \text { statistics in paren } \\
{ }^{*} p<0.10,{ }^{* *} p< \\
{ }^{1} \text { Antidumping inv } \\
{ }^{2} \text { Antidumping inv }\end{array}$ & $\begin{array}{l}\text { hes } \\
0.0 \\
\text { estig } \\
\text { estig }\end{array}$ & $\begin{array}{l}{ }^{* * * *} p<0.01 \text {, base } \\
\text { tions between initi } \\
\text { tions withdrawn at }\end{array}$ & $\begin{array}{l}\text { ed on robust standard error } \\
\text { ation year and revocation y } \\
\text { the request of the domesti }\end{array}$ & $\begin{array}{l}\text { clustered at product level. } \\
\text { ear. } \\
\text { c industry. }\end{array}$ & \\
\hline
\end{tabular}


Third, cartel-related antidumping cases that result in duties or are industry-withdrawn, lead to quantity reductions in world trade. However, in contrast to Table 3, quantity effects are found only for antidumping initiated during cartel activity. It is interesting that the estimated reductions in traded quantities are larger when antidumping cases are withdrawn by the petitioning industry than when they lead to a duty. Our estimates imply that an out-of-court settlement between antidumping-initiating and antidumping-target country helps global cartels more than the imposition of antidumping duties.

\section{Conclusion}

Although antitrust authorities usually investigate anticompetitive behaviour domestically, it is well-known that cartels of multinational firms operate accross international borders (Levenstein et al., 2015). Based on the theoretical foundation developed by Staiger and Wolak (1989), who demonstrate that cartels have an incentive to use antidumping laws strategically, this paper studies empirically whether antidumping laws help globally active cartels to raise world import

prices. This research question is in particular important for the development of international trade policy, where Hoekman et al. (1997, p. 403) already emphasised the need to introduce antitrust criteria into antidumping investigations.

We motivate our empirical work by an early contribution of Messerlin (1990), who observes that roughly one quarter of antitrust cases in the European Commission between 1980 and 1987 were dealing with products that were also involved in antidumping investigations. Thanks to the Global Antidumping Database (GAD) (Bown, 2015) and the Private International Cartels Dataset (PIC) (Connor, 2014b), we are able to track all antidumping cases of 61 globally active cartels between 1992 and 2014. In order to match both databases, we identify and assign relevant 6-digit HS product codes for all globally active cartels in the PIC dataset. Between 1992 and 2014, nearly half of these cartels (27 out of 61) were dealing with products that are matched 
with at least one antidumping case during cartel activity. $70 \%$ of all global cartels, corresponding to $52 \%$ of cartel products, are matched to at least one antidumping case at any time in the sample. In constrast, only 33\% of all products have been involved in an antidumping.

Our empirical results are as follows. Cartel periods are associated with increases in world import prices by 9 to $12 \%$ and reductions in traded quantities by 9 to $11 \%$. As antidumping is a bilateral policy instrument, its implications for world trade are less clear. We find that antidumping cases - that is the time between the initiation year and until the year where antidumping duties are revoked - are associated with decreasing world import prices and increasing world import quantities. A reason behind this effect might be that firms hit by antidumping duties divert their exports to alternative markets.

Antidumping cases initiated before or during the cartel period are associated with increases in world import prices. Thanks to the rich collection of antidumping data (Bown, 2015), we are also able to address the theoretical literature that has analysed withdrawn antidumping cases as a sign of tacit collusion. Prusa (1992) and Zanardi (2004b) have demonstrated that the filing of antidumping petitions provides domestic firms with a tool to facilitate or maintain cartel agreements by negotiating an out-of-court settlement before the conclusion of the antidumping investigation. Our empirical estimates show that industry-withdrawn antidumping initiated during cartel activity is associated with an increase in world import prices by 26 to $47 \%$ and reductions in quantities by 34 to $72 \%$. This effect comes on top of the cartel fixed effect that increases prices and declines quantities. Our results highlight that global cartels may find it more beneficial to negotiate an out-of-court settlement and withdraw the petition rather than to have duties imposed on the foreign firm. Finally, the strong contrast between the impact of antidumping cases in general and antidumping cases that are matched to global cartels highlights the need for antidumping and antitrust authorities to collaborate in their aim to achieve a competitive market environment. 


\section{References}

Agnosteva, D. (2016). International Cartels and Bilateral Trade: An Empirical Investigation. Available at SSRN 2481880.

Agnosteva, D., Syropoulos, C., and Yotov, Y. V. (2020). Preferential Trade Liberaliza-tion with Endogenous Cartel Discipline: Implications for Welfare and Optimal Trade Policies.

Anderson, J. E. (1992). Domino Dumping I: Competitive Exporters. The American Economic Review, pages 65-83.

Anderson, J. E. (1993). Domino Dumping II: Anti-dumping. Journal of International Economics, 35(1-2):133-150.

Bernheim, B. D. and Madsen, E. (2017). Price Cutting and Business Stealing in Imperfect Cartels. American Economic Review, 107(2):387-424.

Beyer, J. (2010). Are Global Cartels More Effective Than "National” Cartels. European Commission. Accessed: 11/11/2020.

Blonigen, B. A. and Park, J.-H. (2004). Dynamic Pricing in the Presence of Antidumping Policy: Theory and Evidence. American Economic Review, 94(1):134-154.

Blonigen, B. A. and Prusa, T. J. (2016). Dumping and Antidumping Duties. In Handbook of Commercial Policy, volume 1, pages 107-159. Elsevier.

Bown, C. P. (2008). The WTO and Antidumping in Developing Countries. Economics \& Politics, 20(2):255-288.

Bown, C. P. (2015). Global Antidumping Database. The World Bank. June. 
Bown, C. P. and Crowley, M. A. (2007). Trade Deflection and Trade Depression. Journal of International Economics, 72(1):176-201.

Bown, C. P. and Crowley, M. A. (2013). Self-Enforcing Trade Agreements: Evidence from Time-Varying Trade Policy. American Economic Review, 103(2):1071-90.

Brander, J. and Krugman, P. (1983). A 'Reciprocal Dumping' Model of International Trade. Journal of International Economics, 15(3-4):313-321.

Conconi, P., DeRemer, D. R., Kirchsteiger, G., Trimarchi, L., and Zanardi, M. (2017). Suspiciously Timed Trade Disputes. Journal of International Economics, 105:57-76.

Connor, J. M. (2014a). Price-Fixing Overcharges: Revised 3rd Edition.

Connor, J. M. (2014b). The Private International Cartels (PIC) Data Set: Guide and Summary Statistics, 1990-2013.

Egger, P. and Nelson, D. (2011). How bad is Antidumping? Evidence From Panel Data. Review of Economics and Statistics, 93(4):1374-1390.

European Commission (2012). Antitrust: Commission Fines Producers of TV and Computer Monitor Tubes $€ 1.47$ Billion for two Decade-Long Cartels. Accessed: 11/11/2020.

Evenett, S. J., Levenstein, M. C., and Suslow, V. Y. (2001). International Cartel Enforcement: Lessons From the 1990s. The World Economy, 24(9):1221-1245.

Flaaen, A. B., Hortaçsu, A., and Tintelnot, F. (2020). The Production Relocation and Price Effects of US Trade Policy: The Case of Washing Machines. American Economic Review, 110(7):2103-27. 
Fonseca, M. A. and Normann, H.-T. (2012). Explicit vs Tacit Collusion-The impact of Communication in Oligopoly Experiments. European Economic Review, 56(8):1759-1772.

Harrington Jr, J. E. (2017). The Theory of Collusion and Competition Policy. MIT Press.

Harrington Jr, J. E. et al. (2006). How do Cartels Operate? Foundations and Trends® in Microeconomics, 2(1):1-105.

Hexner, E. (1943). International Cartels in the Postwar World. Southern Economic Journal, pages $114-135$.

Hoekman, B. et al. (1997). Competition Policy and the Global Trading System. The World Economy, 20(4):383-406.

Irwin, D. A. (1998). The Semiconductor Industry. In Brookings Trade Forum, pages 173-200. JSTOR.

Ivaldi, M., Jullien, B., Rey, P., Seabright, P., and Tirole, J. (2003). The Economics of Tacit Collusion.

Knetter, M. M. and Prusa, T. J. (2003). Macroeconomic Factors and Antidumping Filings: Evidence From Four Countries. Journal of International Economics, 61(1):1-17.

Konings, J. and Vandenbussche, H. (2005). Antidumping Protection and Markups of Domestic Firms. Journal of International Economics, 65(1):151-165.

Konings, J. and Vandenbussche, H. (2013). Antidumping Protection Hurts Exporters: FirmLevel Evidence. Review of World Economics, 149(2):295-320.

Levenstein, M. C., Sivadasan, J., and Suslow, V. Y. (2015). The Effect of Competition on Trade: Evidence From the Collapse of International Cartels. International Journal of Industrial Organization, 39:56-70. 
Levenstein, M. C. and Suslow, V. Y. (2006). What Determines Cartel Success? Journal of Economic Literature, 44(1):43-95.

Messerlin, P. A. (1990). Anti-Dumping Regulations or Pro-Cartel Law? The EC Chemical Cases. The World Economy, 13(4):465-492.

Miller, N. H. (2009). Strategic Leniency and Cartel Enforcement. American Economic Review, 99(3):750-68.

Nieberding, J. F. (1999). The Effect of US Antidumping law on Firms' Market Power: An Empirical Test. Review of Industrial Organization, 14(1):65-84.

Pierce Jr, R. J. (1999). Antidumping law as a Means of Facilitating Cartelization. Antitrust Law Journal, 67:725.

Prusa, T. J. (1992). Why are so Many Antidumping Petitions Withdrawn? Journal of International Economics, 33(1-2):1-20.

Prusa, T. J. (1994). Pricing Behavior in the Presence of Antidumping law. Journal of Economic Integration, pages 260-289.

Prusa, T. J. (2001). On the spread and impact of anti-dumping. Canadian Journal of Economics/Revue Canadienne d'Économique, 34(3):591-611.

Prusa, T. J. (2005). Anti-Dumping: A Growing Problem in International Trade. The World Economy, 28(5):683-700.

Reynolds, K. M. (2013). Under the Cover of Antidumping: Does Administered Protection Facilitate Domestic Collusion? Review of Industrial Organization, 42(4):415-434. 
Röller, L.-H. and Steen, F. (2006). On the Workings of a Cartel: Evidence From the Norwegian Cement Industry. American Economic Review, 96(1):321-338.

Rutkowski, A. (2007). Withdrawals of Anti-dumping Complaints in the EU: A Sign of Collusion. The World Economy, 30(3):470-503.

Staiger, R. W. and Wolak, F. A. (1989). Strategic use of Antidumping law to Enforce Tacit International Collusion. Technical report, National Bureau of Economic Research.

Staiger, R. W. and Wolak, F. A. (1992). The Effect of Domestic Antidumping law in the Presence of foreign Monopoly. Journal of International Economics, 32(3-4):265-287.

Staiger, R. W. and Wolak, F. A. (1994). Measuring Industry Specific Protection: Antidumping in the United States. Technical report, National Bureau of Economic Research.

Taylor, C. T. (2004). The Economic Effects of Withdrawn Antidumping Investigations: Is There Evidence of Collusive Settlements? Journal of International Economics, 62(2):295-312.

Vandenbussche, H. and Zanardi, M. (2010). The Chilling Trade Effects of Antidumping Proliferation. European Economic Review, 54(6):760-777.

Veugelers, R. and Vandenbussche, H. (1999). European Anti-Dumping Policy and the Profitability of National and International Collusion. European Economic Review, 43(1):1-28.

Viner, J. (1966). Dumping: A Problem in International Trade. The WTO and Anti-Dumping I, 393.

Zanardi, M. (2004a). Anti-dumping: What are the Numbers to Discuss at Doha? The World Economy, 27(3):403-433.

Zanardi, M. (2004b). Antidumping law as a Collusive Device. Canadian Journal of Economics/Revue Canadienne d'Économique, 37(1):95-122. 


\section{Appendix}

\begin{tabular}{|c|c|c|c|}
\hline \multicolumn{4}{|c|}{ Commodity List } \\
\hline \multicolumn{4}{|c|}{ Total Commodities defined : 16} \\
\hline SITC: & Rev.1 Rev.2 Rev.3 $\bigcirc_{\text {Rev. } 4}$ & HS: $\bigcirc 92 \bigcirc 96 \bigcirc 02 \bigcirc_{07} \bigcirc_{12} \bigcirc_{17}$ & 17 \\
\hline \multicolumn{4}{|l|}{ вEC } \\
\hline Code & \multicolumn{3}{|l|}{ Description } \\
\hline TOTAL & \multicolumn{2}{|l|}{$\begin{array}{l}\text { Name: ALL COMMODITIES } \\
\text { Description: ALL COMMODITIES }\end{array}$} & $\begin{array}{l}\text { Data Availability } \\
\text { Snapshot }\end{array}$ \\
\hline 85 & \multicolumn{2}{|c|}{$\begin{array}{l}\text { Name: Electrical, electronic equipment } \\
\text { Description: Electrical mchy equip parts thereof; sound recorder etc }\end{array}$} & $\begin{array}{l}\text { Data Availability } \\
\text { Snapshot }\end{array}$ \\
\hline 8540 & \multicolumn{2}{|c|}{$\begin{array}{l}\text { Name: Thermionic and cold cathode valves and tubes } \\
\text { Description: Thermionic, cold cathode or photo-cathode valves and tubes (for } \\
\text { example, vacuum or vapour or gas filled valves and tubes, mercury arc rectifying valves } \\
\text { and tubes, cathode-ray tubes, television camera tubes). }\end{array}$} & $\begin{array}{l}\text { Data Availability } \\
\text { Snapshot }\end{array}$ \\
\hline 854011 & \multicolumn{2}{|c|}{$\begin{array}{l}\text { Name: Colour cathode-ray television picture tubes, monitors } \\
\text { Description: Cathode-ray television picture tubes, including video monitor cathode-ray } \\
\text { tubes :-- Colour }\end{array}$} & $\begin{array}{l}\text { Data Availability } \\
\text { Snapshot }\end{array}$ \\
\hline 854012 & \multicolumn{2}{|c|}{$\begin{array}{l}\text { Name: Monochrome cathode-ray picture tubes, monitors } \\
\text { Description: Cathode-ray television picture tubes, including video monitor cathode-ray } \\
\text { tubes :-- Black and white or other monochrome }\end{array}$} & $\begin{array}{l}\text { Data Availability } \\
\text { Snapshot }\end{array}$ \\
\hline 854020 & \multicolumn{2}{|c|}{$\begin{array}{l}\text { Name: Television camera tubes and other photo-cathode tubes } \\
\text { Description: Television camera tubes; image converters and intensifiers; other photo- } \\
\text { cathode tubes }\end{array}$} & $\begin{array}{l}\text { Data Availability } \\
\text { Snapshot }\end{array}$ \\
\hline 854040 & \multicolumn{2}{|c|}{$\begin{array}{l}\text { Name: Data/graphic display tub } \\
\text { Description: Data/graphic display tubes, colour, with a phosphor dot screen pitch } \\
\text { smaller than } 0.4 \mathrm{~mm}\end{array}$} & $\begin{array}{l}\text { Data Availability } \\
\text { Snapshot }\end{array}$ \\
\hline 854050 & \multicolumn{2}{|c|}{$\begin{array}{l}\text { Name: Data/graphic display tub } \\
\text { Description: Data/graphic display tubes, black and white or other monochrome }\end{array}$} & $\begin{array}{l}\text { Data Availability } \\
\text { Snapshot }\end{array}$ \\
\hline 854060 & \multicolumn{2}{|l|}{$\begin{array}{l}\text { Name: Cathode-ray tubes, nes } \\
\text { Description: Other cathode-ray tubes }\end{array}$} & $\begin{array}{l}\text { Data Availability } \\
\text { Snapshot }\end{array}$ \\
\hline 854071 & \multicolumn{2}{|c|}{$\begin{array}{l}\text { Name: Magnetron tubes } \\
\text { Description: Microwave tubes (for example, magnetrons, klystrons, travelling wave } \\
\text { tubes, carcinotrons), excluding grid-controlled tubes:-- Magnetrons }\end{array}$} & $\begin{array}{l}\text { Data Availability } \\
\text { Snapshot }\end{array}$ \\
\hline 854072 & \multicolumn{2}{|c|}{$\begin{array}{l}\text { Name: Klystron tubes } \\
\text { Description: Microwave tubes (for example, magnetrons, klystrons, travelling wave } \\
\text { tubes, carcinotrons), excluding grid-controlled tubes:-- Klystrons }\end{array}$} & $\begin{array}{l}\text { Data Availability } \\
\text { Snapshot }\end{array}$ \\
\hline 854079 & \multicolumn{2}{|c|}{$\begin{array}{l}\text { Name: Microwave tubes, nes } \\
\text { Description: Microwave tubes (for example, magnetrons, klystrons, travelling wave } \\
\text { tubes, carcinotrons), excluding grid-controlled tubes:-- Other }\end{array}$} & $\begin{array}{l}\text { Data Availability } \\
\text { Snapshot }\end{array}$ \\
\hline 854081 & \multicolumn{2}{|c|}{$\begin{array}{l}\text { Name: Receiver or amplifier valves and tubes } \\
\text { Description: Other valves and tubes :-- Receiver or amplifier valves and tubes }\end{array}$} & $\begin{array}{l}\text { Data Availability } \\
\text { Snapshot }\end{array}$ \\
\hline 854089 & \multicolumn{2}{|c|}{$\begin{array}{l}\text { Name: Electronic valves/tubes, except receiver/amplifier } \\
\text { Description: Other valves and tubes :-- Other }\end{array}$} & $\begin{array}{l}\text { Data Availability } \\
\text { Snapshot }\end{array}$ \\
\hline 854091 & \multicolumn{2}{|c|}{$\begin{array}{l}\text { Name: Parts of cathode-ray tubes } \\
\text { Description: Parts :-- Of cathode-ray tubes }\end{array}$} & $\begin{array}{l}\text { Data Availability } \\
\text { Snapshot }\end{array}$ \\
\hline 854099 & \multicolumn{2}{|c|}{$\begin{array}{l}\text { Name: Parts of electronic valve \& tubes, except cathode ray } \\
\text { Description: Parts :- Other }\end{array}$} & $\begin{array}{l}\text { Data Availability } \\
\text { Snapshot }\end{array}$ \\
\hline
\end{tabular}

Figure A1: UN Comtrade's descriptions for all HS6 codes listed below HS4 8540. We review this list for each version of HS codes (HS92, HS96, HS02, HS07, HS12, HS17). 
Timing of Antidumping and Cartel Product Matches

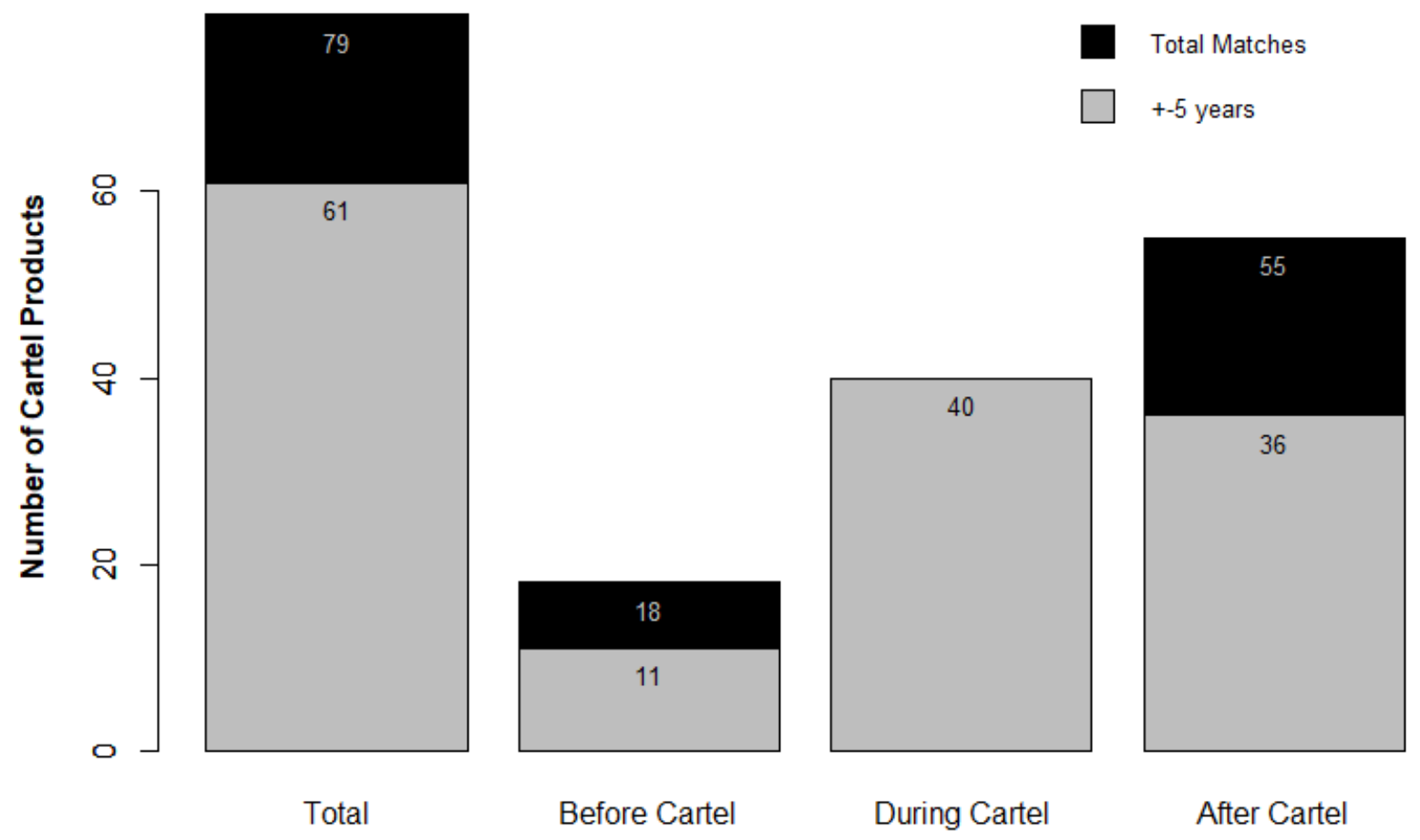

Figure A2: Antitrust and antidumping product matches relative to the cartel period. The figure shows the number of products included in at least one antitrust investigation that are matched to at least one antidumping investigation, relative to the cartel period. 
Table A1: Robustness: More than one Antidumping Case.

\begin{tabular}{|c|c|c|c|}
\hline & $\begin{array}{c}(1) \\
\text { Log Mean Price }\end{array}$ & $\begin{array}{c}(2) \\
\text { Log Median Price }\end{array}$ & $\begin{array}{c}(3) \\
\text { Log Trade-Weighted Price }\end{array}$ \\
\hline Cartel Period & $\begin{array}{l}0.0946^{* * *} \\
(2.64)\end{array}$ & $\begin{array}{c}0.126^{* * *} \\
(2.78)\end{array}$ & $\begin{array}{l}-0.0357 \\
(-0.44)\end{array}$ \\
\hline $\mathrm{AD}$ & $\begin{array}{c}-0.0379^{* *} \\
(-1.98)\end{array}$ & $\begin{array}{c}-0.0611^{* *} \\
(-2.41)\end{array}$ & $\begin{array}{c}-0.0816^{* * *} \\
(-3.22)\end{array}$ \\
\hline Many AD & $\begin{array}{c}-0.0447^{*} \\
(-1.92)\end{array}$ & $\begin{array}{c}-0.0955^{* * *} \\
(-3.20)\end{array}$ & $\begin{array}{l}-0.0445 \\
(-1.58)\end{array}$ \\
\hline AD Before Cartel & $\begin{array}{c}0.0713 \\
(1.11)\end{array}$ & $\begin{array}{l}0.109 \\
(1.36)\end{array}$ & $\begin{array}{c}0.372^{* *} \\
(2.34)\end{array}$ \\
\hline Many AD Before Cartel & $\begin{array}{c}0.421^{* * *} \\
(2.93)\end{array}$ & $\begin{array}{c}0.633^{* *} \\
(2.55)\end{array}$ & $\begin{array}{c}0.295^{* *} \\
(2.46)\end{array}$ \\
\hline AD During Cartel & $\begin{array}{c}0.163^{* * *} \\
(2.94)\end{array}$ & $\begin{array}{c}0.152^{* *} \\
(2.42)\end{array}$ & $\begin{array}{l}0.283 \\
(1.43)\end{array}$ \\
\hline Many AD During Cartel & $\begin{array}{c}0.0536 \\
(0.55)\end{array}$ & $\begin{array}{c}0.0750 \\
(0.81)\end{array}$ & $\begin{array}{c}-0.00202 \\
(-0.01)\end{array}$ \\
\hline AD After Cartel & $\begin{array}{l}-0.0666 \\
(-0.91)\end{array}$ & $\begin{array}{l}-0.139 * \\
(-1.67)\end{array}$ & $\begin{array}{c}-0.236^{* *} \\
(-2.11)\end{array}$ \\
\hline Many AD After Cartel & $\begin{array}{c}0.0353 \\
(0.51)\end{array}$ & $\begin{array}{c}0.0482 \\
(0.60)\end{array}$ & $\begin{array}{l}0.152^{*} \\
(1.69)\end{array}$ \\
\hline Observations & 116,153 & 116,153 & 116,157 \\
\hline Products & 5,649 & 5,649 & 5,649 \\
\hline Product-FE & Yes & Yes & Yes \\
\hline Year-FE & Yes & Yes & Yes \\
\hline
\end{tabular}

$t$ statistics in parentheses

${ }^{*} p<0.10,{ }^{* *} p<0.05,{ }^{* * *} p<0.01$, based on robust standard errors clustered at product level. 
Table A2: Robustness: Five-year lag from the initiation of Antidumping Cases. AD initiated max. 5 years before or after cartel.

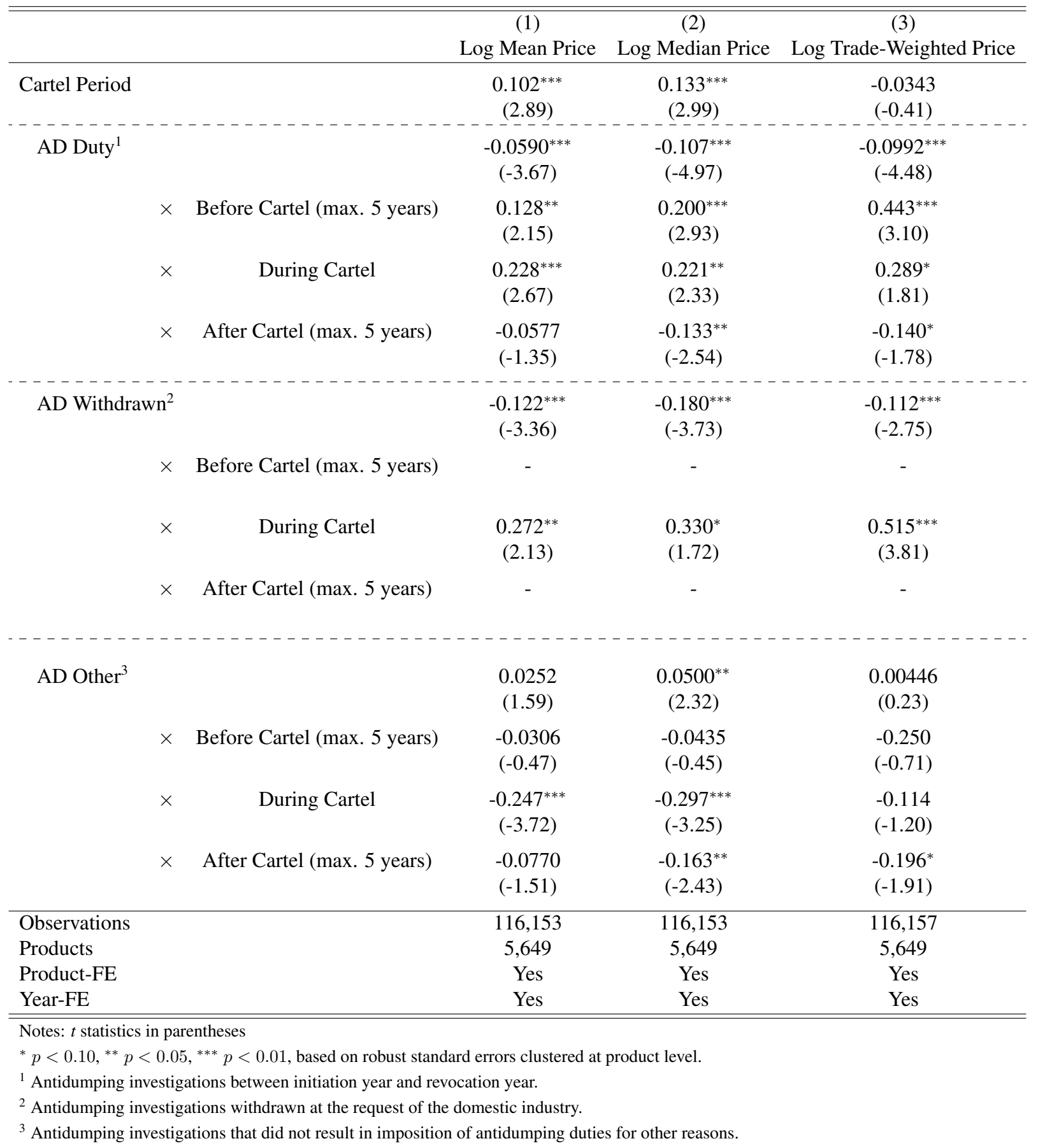




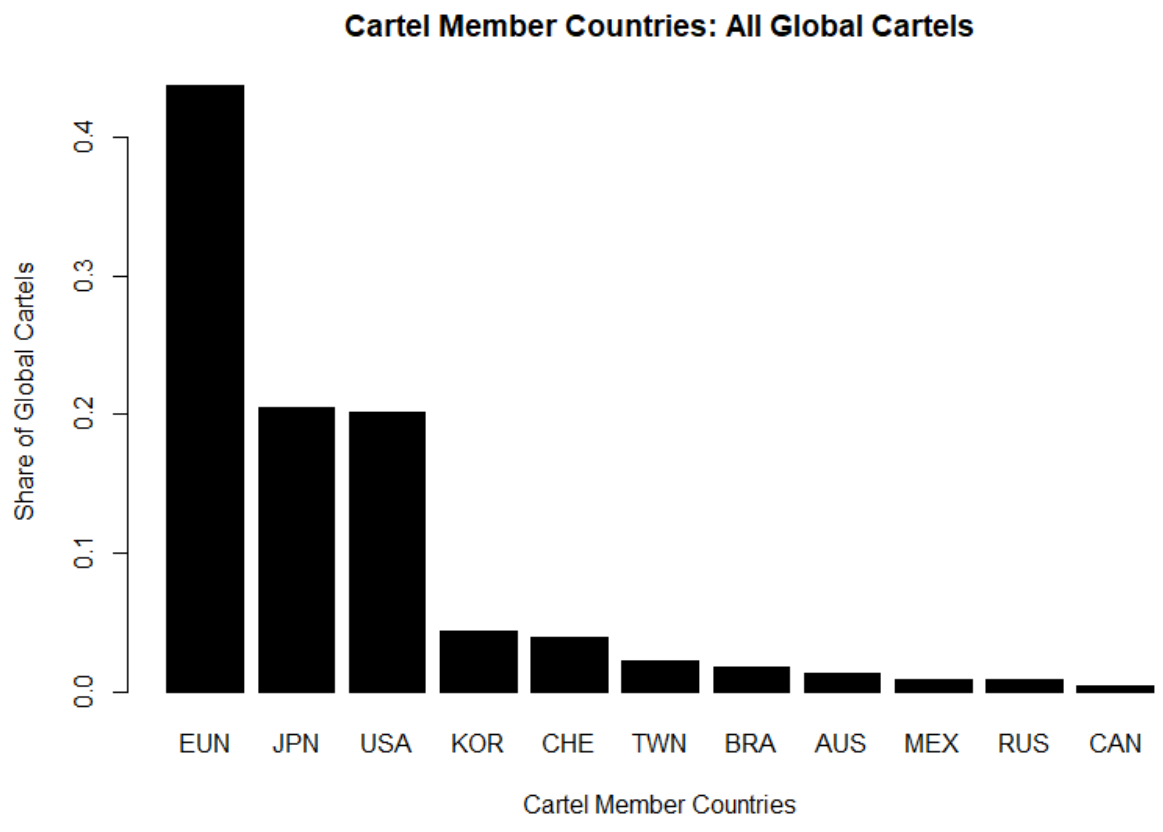

Figure A3: Share of countries involved in 61 global cartels.

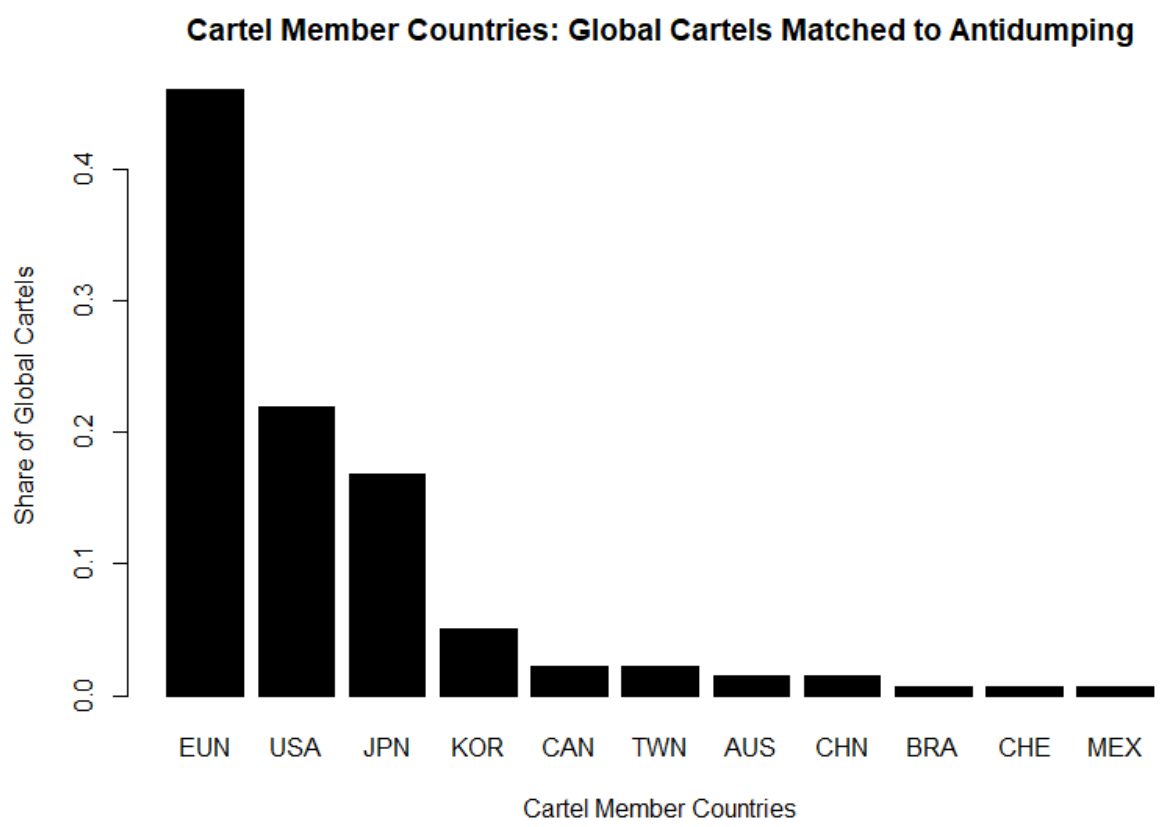

Figure A4: Share of countries involved in the 43 global cartels that are matched to at least one antidumping investigation. 


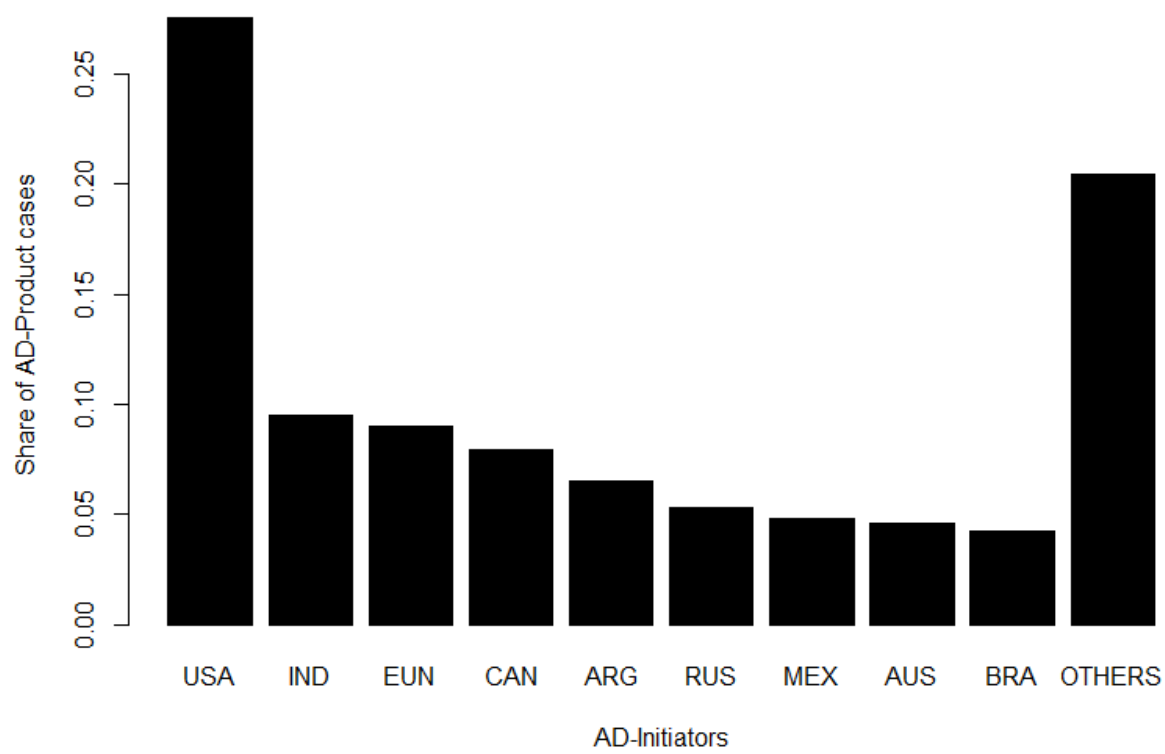

Figure A5: Share of antidumping-initiating countries in the antidumping dataset.

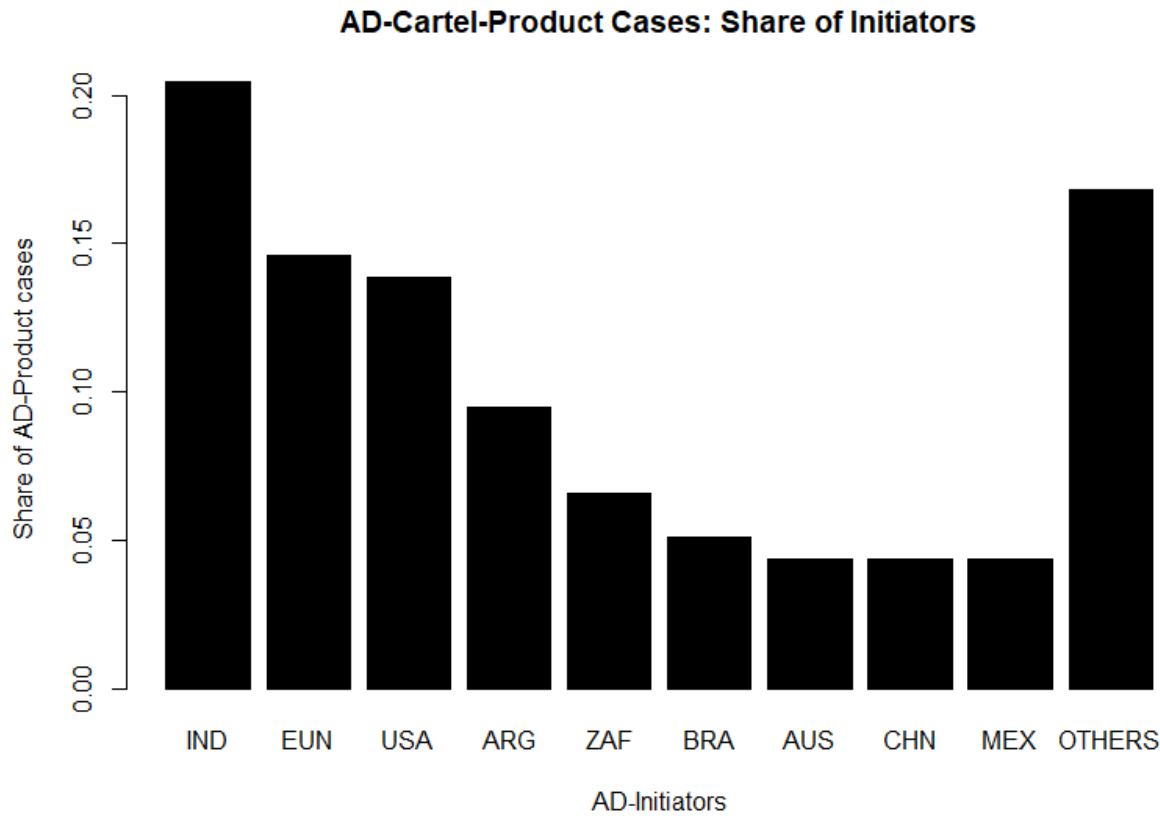

Figure A6: Share of antidumping-initiating countries in the twin antitrust-antidumping dataset. 


\section{AD-Product Cases: Share of Targets}

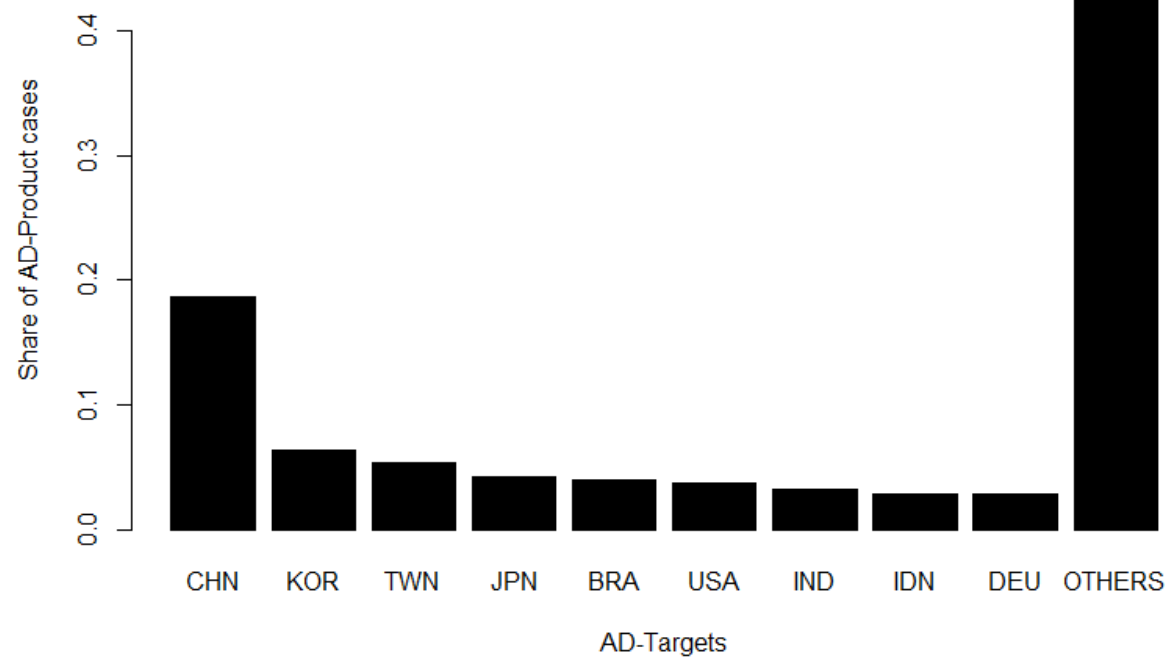

Figure A7: Share of antidumping targeted countries in the antidumping dataset.

AD-Cartel-Product Cases: Share of Targets

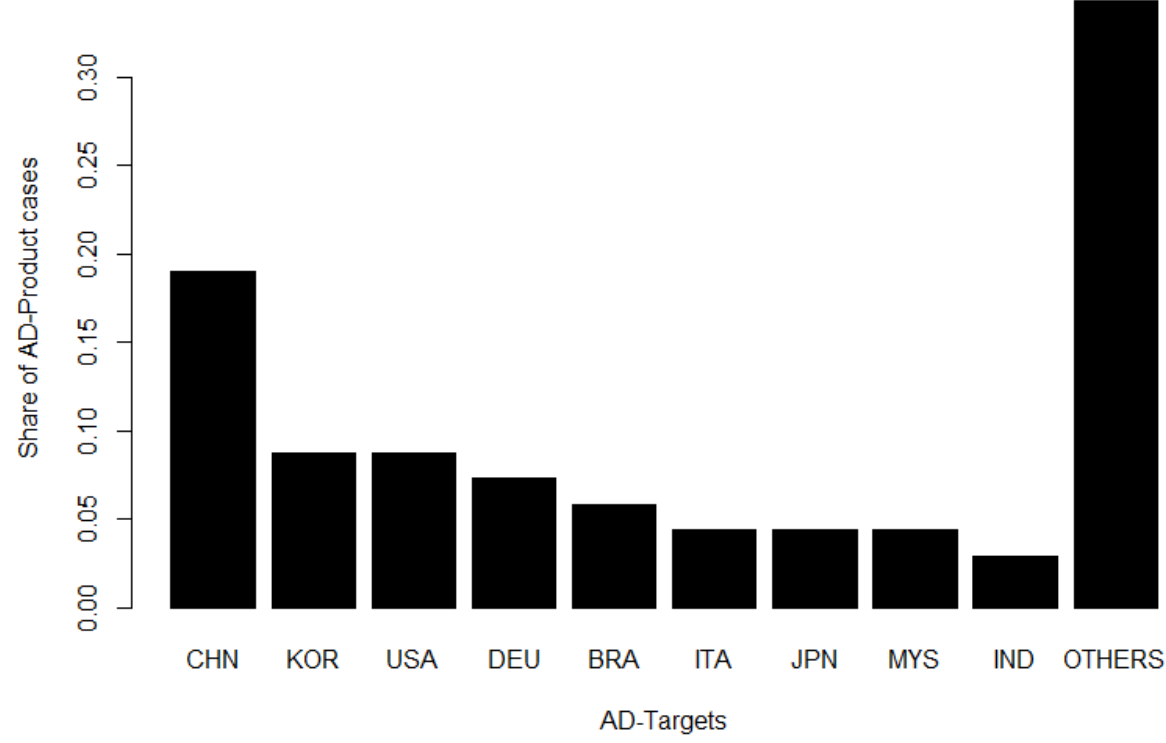

Figure A8: Share of antidumping-targeted countries in the twin antitrust-antidumping dataset. 